\title{
Abstracts of the ASHS Southern Region 53rd Annual Meeting
}

\section{National Sweetpotato Collaborators}

HERBICIDES FOR USE IN SWEET POTATO PLANT BEDS

Wayne C. Porter*, Louisiana State University Agricultural

Center, Louisiana Agricultural Experiment Station, Hammond Research Station, Hammond, LA 70403.

Selected herbicides, alone or in combination with polyethylene bed covers, were evaluated for preemergence weed control in sweet potato plant beds. No injury to sweet potato transplants was found when the herbicide was applied to the soil surface of freshly bedded sweet potato roots before application of the polyethylene or was applied to newly emerged transplants immediately after the bed cover was removed. Some foliar chlorosis was observed in transplants from beds treated with clomazone, but after the first transplant pulling, no reappearance occurred. Clomazone, chloramben, and napropamide provided excellent control of all annual grasses. Herbicides, regardless of timing of application, did not adversely affect number or weight of sweet potato transplants. Beds covered with polyethylene film produced more transplants at the early and total harvests than the uncovered beds.

EFFECT OF HERBICIDES AND WEEDS ON YIELD OF 'EXCEL' SWEETPOTATO.

Dean McGraw* and Bruce Bostian, Department of Horticulture. Oklahoma State University, Stillwater, OK 74078.

Effects of herbicides and weeds were demonstrated by exposing 'Excel' sweetpotatoes to a randomized complete block design of 3 replications of various treatments ranging from phytotoxity to no weed control in 1991 \& 1992 . Plots were either left unweeded, hoed clean or treated with herbicides (sethoxydim, clomazone, metolachlor, imazethapyr) or selective hand weeded to remove broadleaf weeds. Hand weeded treatments were hoed twice. After 120 days weeds remaining in each plot were cut at ground level, dried and weighed. At 125 days the plots were harvested. The roots were cured, graded and weighed. Weed dry weight ranged from zero to nearly $6.5 \mathrm{cwt} / \mathrm{A}$. Weed dry weight as a $\frac{0}{\circ}$ of total marketable sweetpotatoes ranged from zero to $34.5 \%$ in 1991 and zero to 19.8\% in 1992. Competition from grasses reduced sweetpotato yield more than broadleaf weeds. Total marketable sweetpotato yields ranged from zero to $426 \mathrm{cwt} / \mathrm{A}$ in 1991 and from $210 \mathrm{cwt} / \mathrm{A}$ to 289 cwt/A in 1992.

LEAF LOSS EFFECTS ON GROWTH PARAMETERS OF FOUR SWEETPOTATO CULTIVARS

W.J. McLaurin and S.J. Kays

Department of Horticulture, University of Georgia, Athens, GA 30602

Under typical field production conditions, four highyielding sweetpotato cultivars (Centennial, Jewel, Regal and Resisto) were found to lose substantial amounts of leaves due to natural senescense rather than pathological or herbivory causes. Leaf loss by the normal harvest date ranged from $4 \frac{6}{6}$ to $63 \%$ of the total leaves formed in 1991 and 48 to $59 \%$ in 1992. There was a strong positive correlation between leaves lost and the number of vines $\left(r^{2}=0.80\right)$ and nodes $\left(r^{2}=0.89\right)$ per plant. Positive correlations were also found between leaf loss and total dry weight of the plant $\left(r^{2}=0.67\right)$. root fresh weight $\left(r^{2}=0.65\right)$. root dry weight $\left(r^{2}=0.60\right)$, and vine $d r y$ weight $\left(r^{2}=0.68\right)$. Distinct differences were found among cultivars in dry matter allocation within the plant. Of the cultivars in dry matter allocation within the plant. Of the
cultivars tested, 'Jewel' allotted a lower percentage of dry matter into vines and a greater percentage into storage roots. matter into vines and a greater percentage into storage roots. Estimated leaf dry matter losses due to leaf shedding ranged
from 1.2 to $2.6 \mathrm{MT} \cdot \mathrm{ha}^{-1}$. Amount of leaf loss appeared to be closely related to vigorous vine growth and subsequent shading of older leaves, though leaf loss did not have a negative impact on storage root yield in the cultivars tested.

SCREENING FOR STREPTOMYCES SOIL ROT RESISTANCE IN SWEETPOTATO

Petra J. Wolters* and Wanda W. Collins, Department of Horticultural Science, North Carolina State University, Box 7609, Raleigh, NC 27695-7609

Streptomyces soil rot or pox, caused by the actinomycete Streptomyces ipomoea, is a destructive root disease of sweetpotato. Evaluation for resistance to $S$. ipomoea in naturally infested fields, requires much space and results may vary from year to year. In this study a greenhouse method for evaluating the response of sweetpotato clones to infection with $S$. ipomoea was developed. The greenhouse method used fibrous roots, developed on terminal vine cuttings. Experiments showed no time by clone interaction, indicating that this method gave consistent results when repeated. A study to determine corrrelation between field resistance of clones and resistance as found by the greenhouse method was done. Thirty-nine clones were screened for resistance using the greenhouse method and were also planted in a field naturally infested with S. ipomoea. Severity of disease on fibrous roots (greenhouse method) and on storage roots (field method) was evaluated visually using a scale of 0 to 5 (0: no symptoms. 5: severe symptoms). Although correlations between data from the greenhouse and field methods were low 10 moderate $(r=0.17$ to 0.49$)$. extremely susceptible or resistant clones were identified as such by both methods. These results suggest that it is possible to select clones with high resistance to $S$. ipomoea using the greenhouse method, which provides a better controlled environment, and requires less space than field evaluations.

HERITABILITIES FOR SWEETPOTATO WEEVIL RESISTANCE

Paul G. Thompson* and John C. Schneider, Departments of Horticulture and Entomology, Miss. State Univ., Miss. State, MS 39762 and Boyett Graves, South Miss. Exp. Sta., Beaumont, MS 39423

Narrow-sense heritabilities $\left(\mathrm{h}^{2}\right)$ for sweetpotato weevil (Cylas formicarius elegantulus) resistance were estimated in 2 breeding populations. Population A included clones from US programs with previously reported moderate levels of weevil resistance. Population B included clones of US origin plusplant introductions from 14 countries. Parents and progenies were included in field evaluations with no wild weevils present. Weevils were cultured and applied to each plant. Population A was evaluated for 2 years and population B for 1 . The GXE estimate for population A was also used for population B. Heritabilities were estimated by parent offspring regression and variance component analysis. Average h2 for percentage noninjured roots were 0.35 and 0.47 for population $A$ and $B$, respectively. Intermating highest performing genotypes from both populations should increase $h^{2}$ by increasing frequencies of resistance genes. A moderate rate of increase in resistance levels should result from selecting and intermating resistant genotypes. 
SWEETPOTATO FLAVOR - EXISTING STATUS AND FUTUREOUTLOOK J. Kays and Wayne J. McLaurin Department of Horticulture, The University of Georgia, Athens, Georgia 30602

Flavor is a primary trait in the selection of foods. The role of flavor in acceptance of the sweetpotato, flavors status as a selection trait in existing breeding programs, and our current understanding of the flavor chemistry of the sweetpotato was reviewed. The sweetpotato, unlike most staple crops, has a very distinct and dominant flavor. In typical breeding programs, however, flavor is generally one of the last traits screened. A tremendous diversity and range of flavors has been reported within the sweetpotato germplasm (e.g., acidic, bland, baked potato, boiled potato. carrot, chalky, chemical, citrus, earthy, Ipomoeo/terpene, lemon, musty, pumpkin, salty, squash (titer type), starchy, sweet, sweetpotato (traditional), terpene, and turnip. These results indicate that the genetic diversity for flavor present in sweetpotato germplasm will allow making substantial changes in the flavor of new cultivars, thus potentially opening previously unexploited or under-exploited markets. Implementation involves solving two primary problems: 1) identification of desirable flavor ideotypes; and development of procedures that allow maximizing the selection of specific flavor types.

AN EFFICIENT IN VITRO REGENERATION METHOD TO PRODUCE ADVENTITIOUS PLANTS IN SWEETPOTATO

C. S. Prakash*, R. Gosukonda, A. Porobo Dessai, E. Blay and K. Dumenvo. Plant Molecular Genetics Lab, School of Agriculture, Tuskegee University, Milbank Hall, Tuskegee, AL 36088.

Lack of suitable methods to develop adventitious plantlets in vitro is a limiting factor in producing transgenic sweetpotato plants through gene transfer. Studies were conducted to develop an in vitro high frequency regeneration protocol for sweetpotato that is rapid and consistent. When 27 genotypes of sweetpotato were screened, five were identified as highly regenerative (318846-3, PI 531143, Hi Dry,

Rojoblanco and Beauregard). High frequency regeneration of shoots (in 60 to $80 \%$ explants) was observed within 30 days when leaf explants with intact petioles from the apical portions of the in vitro shoots were cultured on a MS medium with 2,4-D $(0.2 \mathrm{mg} / \mathrm{l})$ for three days and then transferred to a medium with zeatin riboside (ZR) $(0.2 \mathrm{mg} / \mathrm{l})$. However, thidiazuron $(0.2 \mathrm{mg} / \mathrm{l})$ had to be substituted for ZR to achieve regeneration of shoots from petiole $(0.5$ to $1 \mathrm{~cm})$ explants (the most responsive organ for transformation by Agrobacterium). Petiole explants developed shoots efficiently (80-90\%) and rapidly (10 to $21 \mathrm{~d}$ ), but were specific to the genotype 318846-3. The resulting plantlets were vigorous and normal, and were transferred to the green house with little or no mortality.

CHEMICAL, PHYSICAL AND SENSORY ATTRIBUTES OF FORMED AND FROZEN BAKED SWEETPOTATO

J.L. Collins* and J.-Y. Liao, Department of Food Science \& Technology, The University of Tennessee, Knoxville, TN 37996-4500

Sweetpotato (SP) provides culinary satisfaction and essential dietary nutrients: vitamins $A$ and $C$, dietary fiber, ccmplex carbohydrates and minerals. Yet, consumption suffers from absence of convenience products. Therefore, objectives were to prepare a convenience-type product of baked SP and to measure selected properties/attributes when reheated. Jumbo, cured/stored roots of 'Southern Delight' (SD) and 'Carolina Bunch' (CB) were baked at $190 \mathrm{C} / 75-90 \mathrm{~min}$ or $204^{\circ} \mathrm{C} / 70-80 \mathrm{~min}$, peeled, cut into pieces, stuffed into cellulose casing, frozen and held 2 and 6 mo. Tests performed were proximate analysis, B-carotene, color and sensory. Solids, less carbohydrates, were higher in $\mathrm{CB}$, the more intensely orange colored. Color was unaffected by baking or storage. Acceptability and desire to purchase were greater for $\mathrm{CB}$ baked at $204 \mathrm{C}$ and stored $6 \mathrm{mo}$. Desirable characteristics included: availability, requiring heating only; textural integrity of baked roots; color and flavor retention to $6 \mathrm{mo}$; portion control; use of jumbo roots and potential for addition of flavorings.

EVALUATION AND BATING OF SENSORY ATTRIBUTES IN BAKED AND CANNED SWEETPOTATOES

Juan L. Silva*, Department of Food Science and Technology, Mississippi State University, Mississippi State, MS 39762 A total of 6 cvs and 14 lines of sweetpotatoes were analyzed by sensory panel for baking and canning quality. Baked samples were cured, washed, foil-wrapped, and baked for Baked samples were cured, washed, foll-wrapped, and baked for $1.5 \mathrm{~h}$ at $177{ }^{\circ}$. Canned samples were lye peeled and finished, packed with $20^{\circ}$ Brix sucrose in $303 \times 406$ cans, and retorted highest on canned samples. In analyzing the different sensory attributes, color uniformity had the highest partial $\mathrm{R}^{2}$ for both baked $(0.61)$ and canned $(0.67)$ products. Moistness $\left(R^{2}=0.13\right)$ and mouthfeel $\left(R^{2}=0.15\right)$ were the subsequent important factors followed by eye appeal, smoothness, lack of fiber and attractiveness. Thus color attributes accounted for $67.0 \%$ sweetpotatoes. Textural attributes followed with flavor being last with $1.0 \%$ and $1.1 \%$. for baked and canned products, respectively. When averaging all samples, eye appeal and color uniformity were below the acceptable rating (6) in baked samples. For canned samples. attractiveness and color intensity were rated the lowest. This work shows that the average or total score given to a cv/line should be the result of the weighted scores of each attribute rated and not the arithmetic mean. Also, breeders should incorporate color intensity uniformity, and susceptibility to browning color early in their program.

\section{J.B. Edmond Undergraduate}

\section{ELECTROPHORETIC ANALYSIS OF SKIN RUSSETING IN POTATO} USING NEAR-ISOGENIC LINES

Leslie Oehlke*, Ramon Torres-Lopez, J. Michele Myers and J. Creighton Miller. Jr., Department of Horticultural Sciences, Texas A\&M University, College Station, TX 77843-2133

The potato (Solanum luberosum, L.) is the fourth most important food crop worldwide and the most important vegetable crop in the United States. The United States is the only country which prefers russet skin potatoes, but plant breeders experience difficulty in manipulating the trait, since the potato is an autosomal tetraploid with complex inheritance. The enzyme banding patterns of white and russet skin potato tubers from five near-isogenic lines were studied in order to identify specific isozyme differences associated with russeting. Tuber skin samples were prepared and run on polyacrylamide gels. The gels were then stained for eight enzyme systems (PRX, EST, MDH, PGM, PGI, GOT, G-6PDH, 6PGDI-I) and scored for banding differences. Peroxidase activity was always associated with russeting, and differences in esterase banding were also observed. Potential markers associated with russeting might have been found, which could provide fingerprinting tools for mapping the gene(s) responsible for russeting in potato

\section{Norman F. Childers Graduate}

\section{EVALUATION OF FUNGAL INFECTION OF PECAN ROOTS WITH} HIGH PRESSURE LIQUID CHROMATOGRAPHY

Monte L. Nesbitt*, J. Benton Storey, Dept. of Horticultural Science Stuart D. Lyda, Dept. of Plant Pathology \& Microbiology, and L.J. Grauke, USDA/ARS, Texas A\&M University, College Station, TX 77843

Rootstock resistance to soil-borne phytopathogenic fungi, such as Phymatotrichum omnivorum (Shear) Duggar, is an important factor in disease control. Measurement of natural rootstock resistance is often based on plant survival/mortality percentage, and /or growth data. Fungal colonization of host roots in disease screening experiments may not be uniform for many reasons, causing variability in host response. Quantification of fungal colonization is needed in order to better understand rootstock performance. Ergosterol, a structural sterol in cell membranes of fungi, is not found in higher plants, and can thus be a measure of fungal colonization. Ergosterol was extracted from roots of pecan seedlings artificially inoculated with $P$. omnivorum and grown in an environmental growth chamber. Analysis of extracts with HPLC revealed that seedlings which were killed in screening, or had low root performance ratings, had increased levels of ergosterol. Non-inoculated controls also contained Ergosterol. indicating contamination and possible competition by other fungi. 
ROOT CONTROL OF URBAN TREES

Patricia R. Knight*, D. Joseph Eakes, and Charles H. Gilliam, Department of Horticulture. Auburn University, Auburn University, AL 36849

Two inch caliper Acer rubrum, Quercus phellos, and Platanus occidentalis were planted March 26, 1990, into 8' x 8' planting holes that were lined with either Typar Biobarrier, Dewitt Pro-5 Weed Barrier or left unlined as a control. There has been little or no root penetration beyond the Biobarrier for the 3 tree species during the first 3 years of this study. At the end of 1990, the control and the Dewitt Pro-5 had similar root penetration numbers. By the end of 1991, the Dewitt Pro-5 had greater root penetration than did the control for A. rubrun. Root penetration of Dewitt Pro-5 and the control treatment was similar for $Q$. phellos and $P$. occidentalis. There were no differences in root penetration for Dewitt Pro-5 and the control in 1992 for any species. There were no differences in height for any tree species following the 1990 or 1991 growing seasons and no difference following the 1992 growing season for A. rubrum and Q. phellos. The control treatment had the grearest height for $P$. occidentalis in 1992. There were no differences in caliper due to root control treatment for the 3 species during the first 3 years of this study.

\section{PHOTOSYNTHESIS AND TRANSPIRATION DURING GROWTH AND DEVELOPMENT OF ALLIUM CEPA L.}

Daniel Warnock*, William Randle, and Mark Rieger, Department of Horticulture, University of Georgia, Athens, Georgia 30602.

Photosynthesis is the very essence of agriculture. Previous photosynthetic and transpirational studies of onion (Allium cepa) have been limited to specific developmental stages. Our study measured photosynthesis and transpiration in sixteen plants of a single short-day cultivar over an eleven week period containing both non- and bulb inductive photoperiods. Differences in weekly means for photosynthesis, leaf conductance, water use efficiency, and intercellular CO, were highly significant. Weekly photosynthetic means increased under a non-inductive photoperiod and peaked one week after initiating a bulb inducing photoperiod. A decrease and leveling period occurred as bulbs developed followed by a decrease as foliage lodged. Weekly photosynthetic and leaf conductance means were correlated and highly significant. Water use efficiency and intercellular $\mathrm{CO}$, means remained fairly constant throughout the study suggesting that photosynthesis in unstressed onions was controlled by internal mechanisms instead of stomata.

\section{THE EFFECT OF THIDIAZURON CONCENTRATION AND 2,4-D EXPOSURE ON SHOOT ORGANOGENESIS IN BIRCH}

Ann M. Chanon* and R. Daniel Lineberger, Department of Horticultural Sciences, Texas A\& M University, College Station, TX 77843 The genus Betula contains many important forest and ornamental species and a method of rapid clonal propagation of superior genotypes is needed. Thidiazuron (TDZ) is a potent synthetic plant growth regulator with cytokinin-like activity. TDZ was used to differentiate shoots after long term exposure to dichlorophenoxyacetic acid (2.4-D) as part of a larger study on clonal fidelity. Birch calli were cultured on Woody Plant Medium supplemented with $10^{-5} \mathrm{M} 2,4-\mathrm{D}$ for up to 30 weeks. The calli were transferred to media containing TDZ at concentrations of $10^{-6}$ to

$10^{-9} \mathrm{M}$. Most of the tissue which had not been exposed to 2.4-D differentiated shoots five weeks after being exposed to $10^{-6} \mathrm{M} \mathrm{TDZ}$. Increasing the of time exposure to 2.4-D or decreasing the concentration of TDZ delayed differentiation. Calli exposed to 2.4-D for more than 18 weeks rarely differentiated shoots regardless of the concentration of TDZ u s e d.

EFFECT OF SALINITY ON IMBIBITION AND GERMINATION RATES OF LUPINE SEEDS.

Rochele C. Strachan* and E.G. Rhoden, G. W. Carver Agricultural Experiment Station, Tuskegee University, Tuskegee AL 36088 Growing crops using poor quality Later can result in poor germination and seedling survival. Low germination rates of various crops in the Bahamas result from the high salinity of the irrigation water. This study investigated the effects of using varying levels of sea water on germination and imbibition rates of lupine (Lupinus albus) seeds. In separate completely randomized design experiments, 100 lupine seeds were placed in conical flasks and either de ionized distilled water (DDW). $100 \%, 75 \%, 50 \%$ or $25 \%$ sea water added to each flask. Seeds ware removed from each flask every hour for the first 8 hours and every six hours thereafter for 48 hours. lmbibition rate is expressed as $\mathrm{mg} / \mathrm{ghr}$ using the formula: (original weight - weight at y hr) $\mathrm{x}$ 1000)/(original weight $\mathrm{x}$ y hrs) Germination of seeds was measured beginning 3 days after imbibition began and the experiments were terminated after 10 days. The highest rate of imbibition $(178.8 \mathrm{mg} / \mathrm{g} / \mathrm{hr})$ was recorded for lupine seeds placed in $25 \%$ sea water and the lowest of $152.8 \mathrm{mg} / \mathrm{g} / \mathrm{hr}$ for seeds placed in $100 \%$ sea water after two hours. Germination ranged between $49 \%(100 \%$ sea water) to $94.7 \%$ for seeds placed in DDW. It would appear that if lupine seeds were primed with $25 \%$ sea water (approximately $150 \mathrm{ppm}, \mathrm{NaCI}$ ) there would be no significant reduction in either the imbibition or the germination rates.

OPTIMAL GROWTH, RAPID ACCLIMATIZATION AND SHIPPING OF CATTLEYA ORCHID IN SINGLE USE SEALED MEMBRANE VESSELS

\begin{abstract}
Laura A. Dellevigne ${ }^{{ }^{1}}$, Jeffrey W. Adelberg ${ }^{2}$, Peter Vergano, Department of Food Science ${ }^{1}$ and Department of Horticulture Clemson University, Clemson, SC 29634. Three-dimensional polypropylene enclosures have been fabricated for the in vitro culture and ex vitro growth of Cattleya orchid propagules. The enclosures consist of: 1) microporous polypropylene membrane for nutrient transfer between liquid media and the growing tissue. 2) molded polypropylene side wall sized for growth of Cattleya orchid plants and flanged to allow heat seals with membranes, and 3) polypropylene membrane(s) top member for light and gaseous transmission. Three commercial clones of Cattleya have been sealed into these enclosures and grown for eight months on unmended MS medium. Contaminated liquid media was effectively isolated from the propagules within the sealed enclosures, and following a bleach treatment with sterile rinses, propagules were returned to aseptic culture. Greenhouse growth of plant tissues in these enclosures will be discussed. Optimization for growth of Cattleya has begun with studies of gas, light and temperature regimes within the sealed enclosures and a comparison of growth on two different nutrient formulations.
\end{abstract}

\section{GERMINATION OF EASTERN REDBUD IN RELATION TO} TESTA ANATOMY

Rodney Jones* and Robert Geneve, Department of Horticulture, University of Kentucky, Lexington, Kentucky 40546

Redbud (Cercis canadensis) is a small woody ornamental legume that has a hard seed coat, which imposes physical dormancy, typical of many legumes. Redbud also possesses an internal embryo dormancy that must be overcome by stratification. In order to observe the relationship between anatomy and germination, seeds were embedded in JB-4 resin during various developmental and germination stages. The seeds were cut longitudinally with a glass bladed microtome, to observe the radicle, vascular traces and testa. It appears that the vascular traces left from the funiculus serve as a weak point in non-dormant seeds that allows the radicle to rupture the testa during germination.

PERFORMANCE OF SELECT RED MAPLE CULTIVARS IN THE SOUTHEAST Jeff L. Sibley*, D. Joseph Eakes, Charles H. Gilliam, and William A. Oozier, Department of Horticulture, Auburn University. Auburn. AL 36849 Performance evaluation of red maple (Acer rubrum L.) selections in the southeastern U.S. was initiated in November 1988. Seven cultivars, 'Autumn Blaze', 'Autumn Flame', 'Morgan', 'Northwood', 'October Glory', 'Franksred' (Red Sunset TM) and 'Schlesingeri', from tissue culture and a group of seedlings obtained from a single source were container grown for 18 months prior to field planting in March 1990. All plants have received drip irrigation in the 
field. Since field planting, 'Autumn Flame', and 'Autumn Blaze' exhibit the greatest growth rate based on annual height and caliper data. 'Schlesingeri' and 'Northwood' had the least growth. Gas-exchange measurements taken in June 1992, showed 'Schlesingeri' and 'Northwood' to have the greatest photosynthetic activity and transpirational water loss while 'October Glory' and 'Frankred' had the least. white on black (W/B), laminated black on white (B/W), IRT-76 (IRT), AL-OR brown (ALOR), and a bare ground (BG) check. In the first season the highest yields for 'Chandler' were obtained on IRT, followed by CLR, ALOR, $\mathrm{B} / \mathrm{W}, \mathrm{BLK}, \mathrm{W} / \mathrm{B}$, and BG. The highest yields for 'Selva' were on CLR followed by BLK, ALOR, IRT, B/W, W/B, and BG. In the second season the highest yields for 'Chandler' were on W/B followed by BLK. ALOR, IRT, B/W, CLR, and BG. In the case of 'Selva' ALOR was the top performing treatment followed by IRT, W/B, BLK, B/W, BG, and CLR.
APPLE TREE GROWTH DURING TWO SEASONS FOLLOWING SOIL PREPLANT TREATMENTS

Ken Kupperman* and Curt R. Rom, Department of Horticulture and Forestry, University of Arkansas, Fayetteville, AR 72701

The effect of soil preplant strategies winter solarization and methyl bromide fumigation were compared to a non-treated control on apple tree growth. Treatments were applied in the fall after removal of an existing orchard with spring planting of 'Jonee' and 'Smoothee Golden Delicious' on M.26 EMLA rootstock. Soil fumigation significantly increased shoot length in first year, trunk cross-sectional area increase during two seasons, and bloom and set in second year. The control and winter solarization treatments were similar in all responses. Foliar Mn concentrations were significantly lower with fumigated trees in second years compared to other two treatments, which were similar.

\section{Fruit Science}

\section{LIPID CONTENT AND QUALITY OF PECAN POLLEN}

Tommy E. Thompson* $\star^{1}$, Samuel D. Senter ${ }^{1}$, L.J. Grauke

'U.S. Department of Agriculture, Agricultural Research Service, Pecan Breeding and Genetics Research, Somerville, Texas, 77879.

'U.S. Department of Agriculture, Agricultural Research Service, R. B. Russell Agricultural Research Center, Athens, Georgia, 30613.

Pollen from five cultivars (cvs.) of pecans (Carya illinoinensis (Wangenh.) K. Koch] was sampled at Brownwood and College Station, Texas, in 1991 and 1992. Samples were analyzed for cytoplasmic lipid classes and constituent fatty acids. Lipid classes in all cvs. included phosphatidyl inasitol, phosphatidyl swine, phosphatidyl choline, phosphatidyl glycerol, phosphatidyl ethanolamine, free fatty acids, and triglycerides. Triglycerides were the predominant class of lipids in all cvs. analyzed. Fatty acids, qualitated and quantitated by gas chromatographic-mass spectral analysis, included palmitie $(16: 0)$, stearic $(18: 0)$, oleic $(18: 1)$, linoleic $(18: 2)$, and linolenic (18:3) adds. Quantities of individual and total fatty acids were significantly influenced ( $P>0.05$ ) by tree age. Within a uniform age class, quantitie of individual and total fatty acids varied greatly and were significantly influenced by cultivar, year, and location as well as by interactions of main effects. The percent composition of individual fatty acids was stable in relation to total fatty acids in the sample, despite wide variation in quantities of fatty acids in different samples. Total fatty acids varied from $2.53 \%$ to $0.25 \%$ of dry weight. How this large variability in stored energy levels among pollen sources may affect orchard production is discussed.

STRAWBERRY PERFORMANCE USING THE ANNUAL HILL

PLASTICULTURE SYSTEM IN ALABAMA

David G. Himelrick* and W.A. Dozier Jr., Department of Horticulture, Auburn University, Auburn, AL 36849 A number of strawberry cultivars and breeding line selections have been tested in the annual plasticulture system. The only two cultivars currently recommended based on cultural and economic performance ate 'Chandler' and 'Oso Grande'. Plant type (fresh dug, plug, etc.) and nursery source have also been evaluated. Fresh dug nursery source have also been evaluated. Fresh dug
plants with leaves intact generally perform better than plants with leaves intact generally perform better than
those with leaves removed. Rooted runner tips in cell those with leaves removed. Rooted runner tips in cell
packs (plug plants) look very promising and outperform fresh dug plants in most situations. Plastic mulch fresh dug plants in most situations. Plastic mulch
treatments included clear (CLR), black (BLK), laminated
PLANT PARASITIC NEMATODES ASSOCIATED WITH RABBITEYE, SOUTHERN HIGHBUSH AND HIGHBUSH BLUEBERRIES

John R. Clark* and Robert Robbins, University of Arkansas, John R. Clark* and Robert Robbins, Univers
Fruit Substation, Clarksville, AR 72830

Two replicated blueberry plantings, one containing one highbush, (Vaccinium corymbosum) two southern highbush and two rabbiteye (V.ashei) cultivars, and another containing one highbush and three rabbiteye cultivars were sampled in October, 1991 and plant parasitic nematodes extracted and counted. Additionally, 15 commercial rabbiteye plantings were sampled. Standard and southern highbush samples had total plant parasitic nematode levels of 228-451 nematodes $/ 250 \mathrm{ml}$ soil compared to 4-14 nematodes/250 ml soil for rabbiteye. No difference in nematode population was found among the standard highbush ('Bluecrop') and southern highbush ('Cooper', 'Gulfcoast') cultivars. Xiphinema americanum was the most common nematode species found, along with very small populations of Paratrichodorus minor. All with very small populations of Paratrichodorus minor. All commercial plantings had lower nematode levels in samples from the blueberry plants as compared to those from the sod middles between the rows. Nematode levels from commercial plantings ranged from 1477/250m1 soil from blueberry plants and 11-1546/250 $\mathrm{ml}$ soil from the sod middles. Species found at high levels in the sod samples were usually distinctly different from those found associated with the blueberry plants.

EFFECT OF HYDROGEN CYANAMIDE (DORMEX) ON REPLACING LACK OF CHILLING IN 'RUSTON RED' PEACH

Arlie A. Powell*, Scott Goodrick, Ed Tunnell and Richard Murphy, Department of Horticulture, Auburn University. AL

Inadequate winter chilling periodically becomes a serious problem for the commercial peach industry in the Southeast, especially along the Gulf coast. A number of countries around the world are using hydrogen cyanamide (Dormex-SKW) to replace lack of chilling in peaches and other fruit plants. Studies were conducted over 3 years (1990-1992) to evaluate the effects of hydrogen cyanamide on replacing lack of winter chilling in 'Ruston Red' peach, (850 hour chill requirement). Findings indicated full tree sprays in early fall and late winter (after buds had become active) caused excessive bud thinning and crop reduction. Applications made when 65 to $85 \%$ of chilling requirement was satisfied (no visible bud activity) were very effective at concentrations of 0.5 to $1.0 \% \mathrm{~V} / \mathrm{V}$ of $49 \%$ Dormex. Rates above 2\% were very toxic causing crop loss. Dormex effectively replaced a shortage of 265 chilling hours of 'Ruston Red' during one season resulting in full cropping while controls failed to crop.

BLOOM APPLICATIONS OF GIBBERELLIC ACID INCREASE FRUIT SET AND YIELD OF RABBITEYE BLUEBERRIES IN FLORIDA

J.G. Williamson* and R.L. Darnell, Horticultural Sciences Department, University of Florida, Gainesville, FL, 32611-0690

Six-year-old, field-grown 'Beckyblue' and 'Bonita' rabbiteye blueberries were sprayed to drip with Pro-Gibb $\left(250 \mathrm{ppm} \mathrm{GA}_{3}, 0.1 \%\right.$ surfactant, $\mathrm{pH}$ 3.1). Two spray applications were made. The first spray was applied at $80-90 \%$ full bloom followed by a second spray 10 days later. Fruit were

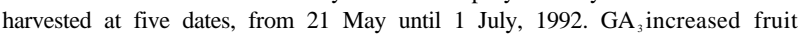
set and doubled total fruit yield for both cultivars compared to the control. Fruit yield was greater for the $\mathrm{GA}_{3}$ treatment than for the control at harvest dates 3 through 5 for 'Beckyblue', and dates 4 and 5 for 'Bonita'. Average berry weight for both cultivars and for both treatments declined as the season progressed. For 'Beckyblue', average berry weight did not differ between treatments at most harvest dates. For 'Bonita', average berryweight was less for the $\mathrm{GA}_{3}$ treatment than for the control at harvest dates 3 through 5 . $\mathrm{GA}_{3}$ increased yield of rabbiteye blueberry with little detrimental effect on fruit size. However, results from Georgia suggest that greater positive effects on fruit set should be possible. 
THE EFFECTS OF SUMMER PRUNING ON APPLE TREE CANOPY MICROCLIMATE AND FRUIT QUALITY

Ray Allen*, Curt Rom, and John Aselage, Department of Horticulture and Forestry, University of Arkansas, Fayetteville, AR 72701

Summer pruning effects on apple tree canopy microclimate, fruit quality, and summer disease were studied in a commercial orchard in eastern Arkansas. Eighteen lo-year-old trees of 'Golden Delicious'/M111 were treated as follows: 1) non-pruned control, 2) moderate pruned, thinning cuts in the canopy, and 3) heavy pruned, thinning cuts in the canopy and heading shoots on the canopy periphery. Treatments were applied on 23-June, 1992. All trees were dormant pruned. PPFD and relative evaporation (RE), measured with Livingston atmometers, were measured at time of treatment, on 15-July, and at Harvest, 9-Sept. PPFD and RE were immediately increased by summer pruning but by harvest had returned to levels near the non-pruned control. Fruit firmness, titratable acidity, starch, and color were not significantly affected while soluble solids were inconsistently affected. Weight was decreased insignificantly by moderate pruning and decreased slightly by heavy pruning. Summer fruit rot incidence was similar among all treatments. PPFD and RE were significantly higher in upper positions of the canopy as compared to lower positions.

\section{INFLUENCE OF A SOIL SPIKE AERATOR ON INCREASING NUT} SIZE AND YIELD OF PECAN TREES

\section{Dan Chapman. Laurence Sistrunk, and J. Benton Storey, Department of} Horticultural Science. Texas A\&M University, College Station. TX $77843-$ 2133 .

Objectives of this experiment were: 1) to determine what effect a soil spike aerator had on nut quality and yield, and 2) to determine whether soil compaction influenced nut quality and yield.3)to determine whether tree stress influenced nut quality or yield on pecan trees In 1990, a randomized design was set up in a 33 year old orchard on Westwood silty clay loam with 3 main treatment factors: 1990 nut size (measure of tree stress), aeration, and cultivar. Location for this experiment was the Adriance Orchard on the Texas A\&M Plantation - Brazos River flood plain. Nut quality was determined by the $\%$ kernel and \# nuts / kg. Yield was measured in $\mathrm{kg}$ per tree. Results after two years showed that aeration increased the nut size of stressed trees in 1991 and non-stressed trees in 1992 Yield was unaffected by aeration in both years but stressed trees produced lower yields in 1992. Aeration increased nut size, but not significantly from 119 nuts/kg to 111 nuts/kg in 1991 . There was a significant increase with aeration in 1992 from 121 nuts $/ \mathrm{kg}$ to 113 nuts $/ \mathrm{kg}$. Yield and \% kernel were not significantly different for both years with aeration Stress did not increase \% kernel in either 1991 or 1992 but nut size was larger on non-stressed trees for both years. Stressed trees produced fewer nuts per tree in 1992.

\section{ADAPTABILITY OF ASIAN PEARS TO SOUTH CAROLINA'S SANDHILLS REGION \\ Gregory L. Reighard* and Terry Guinn, Department of Horticulture, Clemson University, Clemson, SC 29634 \\ An Asian pcar variety trial planted in 1989 near Columbia, South} Carolina was evaluated for growth, productivity, and disease resistance for 4 years. A total of 13 cultivars were observed. The Chinese types $\mathrm{Ya} \mathrm{Li}$ and Shin $\mathrm{Li}$ reached full bloom in mid-March 2 weeks before the Japanese types. The latest blooming cultivars were Choju and Twentieth Century. Shinsei, Shin Li, and $\mathrm{Ya} \mathrm{Li}$ were the most vigorous cultivars, whereas Niitaka, Shinko, and Shinsui were the least vigorous. Most cultivars produced suckers on the Betulaefolia rootstock; however, few suckers were observed for Chojuro, Shinseiki, Shinko, and Ya Li. Fruit production began in the third year, and after the fourth year Shinseiki, Twentieth Century, Choju, Shinko, and Kosui were the most productive cultivars (8.1-18.2 kg/tree). Chinese types were not precocious but did produce the largest fruit (203-270 g). Choju ripened the earliest (early July), and the Chinese types ripened the latest (late August). Fireblight had infected few trees after 4 years and still was not a problem at this location.

PEACH ROOTSTOCK PERFORMANCE IN ARKANSAS

Robert D. Bourne* and Curt Rom, University of Arkansas Fruit Horticulture and Forestry, Fayetteville, AR 72701

Several trials were conducted to compare standard and potential peach rootstocks. The NC-140 trial, with 'Redhaven' as the scion, included 'Halford', 'Siberian-C', 'Bailey', 'GF-677', 'GF-655.2', 'Damas', 'Citation', 'Lovell' and 'GF-43' rootstocks. All trees with 'Citation' as the rootstock died in the first three years. while 'CF-43' and 'Siberian-C' had low survivability and productivity. 'Damas' and 'GF-43' suckered profusely. 'Lovell' trees bloomed an average of one-to-three days later than all other entries. 'Halford'. 'GF-677', 'Bailey' and 'Lovell' had the highest yields. A trial comparing 'Loring' own-root and on 'Tennessee Natural' resulted in similar yields among stocks, but larger fruit and tree size with the own-root trees. 'Redskin' own-root and on 'Lovell' also resulted in similar yields among stocks, and larger tree and fruit size with ownroot trees. A trial using the processing peach selection A219 as the scion on 'S-37' 'Chum Li Tao', AR-78118, 'Yarbrough Cling' and 'Lovell' resulted in highest yields and yield efficiency with 'Yarbrough Cling', 'Lovell' and 'S-37' rootstocks.

THE VIRULENCE OF FOUR BITTER ROT ISOLATES (GLOMERELLA CINGULATA) ON 'GOLDEN DELICIOUS' APPLE FRUITS

Yan Shi*. C.R. Rom, and J.C. Correll, Department of Horticulture and Forestry, University of Arkansas, Fayetteville, AR 72701

Apple bitter rot, caused by Glomerella cingulata is an economically important disease in the Southeastern U.S. Development of resistant cultivars may be an important way to control this disease. To evaluate the apple germplasm resistance, it is necessary to understand variation in virulence of isolates so that appropriated isolates can be selected for screening procedures. Examination of virulence was performed on four Arkansas isolates (G667, G668, G959 and G960) on 'Golden Delicious' fruit. The fruit were wound-inoculated with a $100 \mu \mathrm{l}$ spore suspension $(10$ spores $/ \mathrm{ml}$ ), then incubated in dew chamber at $28 \mathrm{C}$ and $100 \%$ RI-I. Differences in virulence were detected among the isolates in terms of lesion diameter and depth. Isolate G959 was statistically $(\mathrm{p}=.05)$ more virulent than two isolates (G667 and G668) examined. Additional isolates from difference geographical locations will be examined for virulence in future studies.

YIELD AND VEGETATIVE GROWTH OF HIGHBUSH BLUEBERRIES AS INFLUENCED BY IRRIGATION REGIME

W. Keith Patterson* Department of Horticulture, University of Arkansas, Fayetteville, AR 72701 Five year old 'Bluecrop' blueberry plants were subjected to five irrigation regimes over a two year period to determine the influence on yield, berry weight, and plant growth. The plants were in 140 liter open-ended barrels to isolate different rates of moisture application. Ten plants/ treatments were utilized in this study, with each plant considered a rep. Total yields did not follow a predictable pattern. Plants receiving 12 and 16 liters of water $3 \mathrm{x}$ per week produced larger berries, and resulted in larger dry weights at termination of this study. Plants receiving 20 liters $1 \mathrm{x}$ per week produced smaller berries than other treatments, lower yields in year 2, and smallest dry weight at end of the study.

USE OF NAA AS A PECAN NUT THINNER

Ray E. Worlev*, Department of Horticulture, University of Georgia Coastal Plain Experiment Station, Tifton GA 31793-0748

NAA was applied to pecan nuts at concentrations of $0,20,50,100,200$, and $500 \mu \mathrm{g} \cdot \mathrm{g}^{-1}$ on May 19, June 16, and July 20 . The $500 \mu \mathrm{g} \cdot \mathrm{g}^{-1}$ concentration induced nut drop at all dates but was phytotoxic to leaves when applied on May 19. Concentrations of 50-100 $\mathrm{\mu g} \cdot \mathrm{g}$ reduced preharvest drop of nuts. 
THE EFFECT OF SEASON ON DICHOGAMY PATTERNS IN PECAN.

L. J. Grauke* and Tommy E. Thompson, U.S. Department of Agriculture, Agricultural Research Service, Pecan Breeding and Genetics Research, Somerville, TX 77879.

Thirteen cultivars of pecan [Carya illinoinensis (Wangenh.) K. Koch] were monitored for bud break, pollen shed and stigma receptivity for 4 years at LSU Pecan Station, Robson, LA. Cultivars were generally consistent in displaying clear patterns of protogyny or protandry, although patterns were uncertain for some cultivars in some years. Mean dates of cultivar phenology varied significantly by year. Years with warm winter and spring temperatures had earlier seasons of growth and flowering than years with cooler temperatures. The duration of pollen shed and stigma receptivity varied between years.

Protogynous cultivars, as a group, had greater bloom overlap than protandrous cultivars, although overlap varied between years for both dichogamy classes. The sequence of cultivar flowering relative to other cultivars varied between years, resulting in variable amounts of bloom overlap between cultivars in different years.

\section{ROOTSTOCK AFFECTS TREE GROWTH AND PRUNING REQUIREMENT}

Curt R. Rom, Department of Horticulture and Forestry, University of Arkansas, Fayetteville, AR 72701

As part of the NC-140 rootstock evaluation trials, 'Starkspur Supreme Delicious' on 18 rootstocks planted in 1984 were evaluated for growth and pruning requirement. After 9 seasons, trees on the P.22 produced the smallest trees, $1.1 \mathrm{~m}$ width and $1.7 \mathrm{~m}$ height. The stocks P.16, P.2 and Bud.9 produced trees 2.0-2.2 m wide and 2.1-2.6 m tall. Trees on MAC.39, C.6, MAC 1, M.26 EMLA P.1, BUD.490, M.7 EMLA, CG.24, and domestic seedling were 2.9-3.4 m wide and 3.7-4.3 m tall. The largest trees were on P.18 and M.4; $3.6 \mathrm{~m}$ wide and $4.2 \mathrm{~m}$ tall. Dormant pruning time in two seasons significantly increased at an exponential rate with increasing tree width and height. An asymptote for maximum pruning time had an x-axis intersection at approximately 2.7 $\mathrm{m}$ tree height. Pruning time per tree significantly increased in a linear manner with increasing trunk cross section. When pruning time was calculated on a per hectare basis, trees planted at 1460 to 2000 trees/ha required less pruning time than when planted at $\leq 750 \mathrm{tr} / \mathrm{ha}$ or $\geq 4000 \mathrm{tr} / \mathrm{ha}$. Trees on P.16, P.2, Bud.9 and C.6 required the least pruning per unit of fruit production.

\section{Vegetable Crops}

GROWTH OF SWEETPOTATO IN HYDROPONIC SYSTEMS USING SPLIT-ROOT CHANNELS

M.A. Sherif, P.A. Loretan, A.A. Trotman*, J.Y. Lu and L.C. Garner, Tuskegee University NASA CELSS Center. George Washington Carver Agricultural Experiment Station. Tuskegee, AL 36088

Nutrient technique (NFT) and deep water culture (DWC) hydroponic systems were used to grow sweetpotao to study the effect of four nutrient solution treatments on: translocation of nutrients and plant and microbial population growth in split-root channels 'TU-155' cuttings $(15 \mathrm{~cm})$ were prerooted for 30 days in sand in $4 \mathrm{~cm}$ CPVC pipes $46 \mathrm{~cm}$ in length. A modified half Hoagland (MHH) solution was supplied ad libidum. After 30 days, plants were removed and the roots of each plant were cleaned and split evenly between two channels $(15 \mathrm{~cm}$ deep by $15 \mathrm{~cm}$ wide by $1.2 \mathrm{~m}$ long). four plants per channel. Nutrient solution treatments (replicated) were: MHH-MHH: MHH-Air, MHH-deionized water (DIW); and monovalent (Mono) - divalent (Dival) anions and cations. Solution samples were continuously collected at 7-day intervals for microbial population profiling. Plants were harvested after growing for 120 days in a greenhouse. Storage roots, when produced, were similar in nutritive components. However, no storage roots were produced in Air or Mono channels and only a few in DIW. Fresh and dry weights for storage roots and foliage were highest in MHH-MHH in both NFT and DWC in repeated experiments. Population counts indicated that nutrient solution composition influenced the size of the microbial population in NFT. Population counts were highest in Dival channels. The microbial population counts $(4.20-7.49 \mathrm{cfu} / \mathrm{mL})$ were. relatively high in both NFT and DWC systems.
EFFECTS OF SEQUENTIAL FOLIAGE TOPPING ON YIELD OF TWO SWEETPOTATO CULTIVARS

P.P. David*, C.K. Bonsi, E. Bonsi, R.D. Pace, O. Clark and L.C. Garner Carva Agricultural Experiment Station, Tuskegee University. Tuskegee, AL 36088.

The effects of sequential foliage topping on two sweetpotato [Ipomoea batatas $(\mathrm{L})$ Lam cvs Georgia Jet, TU-82-18921 cultivars were investigated in a field trial. Three initial foliage cuttings ( $15 \mathrm{~cm}$ cutting from the growing tip) were initialed at 45.60 and 75 days after planting (DAP). Each initial cutting date was followed by zero, one or two cuttings at biweekly intervals.

Total storage root yields were not affected by cutting treatments regardless of the cultivar investigated. Both cultivars differed in their response in dry matter accumulation, while Georgia Jet was not affected by cutting treatments, TU-82-1892 accumulated less dry matter when foliage tips were removed twice during the growth cycle (75.90 DAP) compared to all other cutting treatments.

The amount of foliage tips removed from each cultivar differed significantly over all treatment levels with Georgia Jet producing more foliage tips than TU-82-1892. However. production of foliage tips for both cultivars was greatest when foliage cutting was delayed until 75 DAP.

THE EFFECT OF MID-SEASON VINE REMOVAL ON THE GROWTH OF FIVE SWEETPOTATO (IPOMOEA BATATAS L.) CULTIVARS

Victor A. Kahn*, C. Stevens, T. Mafolo, C. Bonsi, J.Y. Lu, E.G. Rhoden, M.A. Wilson, M.

J.E. Brown, K. Kabwe and Y. Adeyeye Dept. Plant \& Soil Science Tuskegee Univ. Tuskegee Inst. AL. 36088. Dept, Horticulture. Auburn Univ.. Auburn AL. 36849

TU-82-155 and 'Georgia-Jet' early maturing. 'Carver II', TU-1892 and 'Rojo-Blanco' late maturing sweetpotato, cultivars were evaluated in the field for 0.20 and $40 \%$ vine remova (VR) at $8 \mathrm{wk}$ after transplanting. Parameters measured were: leaf area index (LAI) recovery, net assimilation rate, foliage crop growth rate (FCGR), storage roots crop growth rate (RCGR). alpha a (the mean relative growth rate in dry wt to the mean relative growth rate in leaf area over a time interval) or the partitioning of assimilates, total and marketable yield. A split. splitplot design was used and plants were sampled at 3 and $8 \mathrm{wk}$ following VR. Except for TU82-155 all cultivars showed significant LAI recovery above the control at 3 and 8 wk after vine removal when $20 \%$ of the vines were removed while at the $40 \%$ VR, only 'Georgia-Jet'. TU-1892 and 'Carver II' showed significant increases in LAI for the same periods. Net assimilation rate showed significant interactions while FCGR was not significantly affected assimilation rate showed significant interactions while FCGR was not significantly affected
by either 20 or 40 VR compared to the control at 3 or 8 wk after VR. RCGR was significantly affected by both levels of VR at 3 and 8 wk after VR and surplus assimilates (alpha a) cantly affected by both levels of VR at 3 and $8 \mathrm{wk}$ after VR and surplus assimilates (alpha a)
showed significant interactions between cultivars and \% VR. Told yield declined for all cultivars irrespective to maturity groups with the sharpest decrease being at the $20 \%$ VR. All cultivars except TU-82-155 showed a decrease in marketable yield, the increase in marketable yield of TU-82-155 was due to a lower non-marketable yield.

RESPONSE OF HYDROPONICALLY GROWN SWEETPOTATO TO INOCULATION WITH AZOSPIRILLUM

A.A. Trotman*, W.A. Hill, D.G. Mortley, P.P. David and P.A. Loretan, Tuskegee University NASA CELSS Center, Carver Agricultural Experiment Station, Tuskegee., Al
36088

The effect of inoculation with Azospirillum brasilense strain $\mathrm{Cd}$ on mineral concentration in sweetpotato, [Ipomeo batatas (L) Lam cv. TI-155] tissue and ionic composition of plant nutrient solution was investigated in a greenhouse study. In the field, inoculation of sweetpotato with Azospirillum spp. has been reported to enhance. sweetpotato yield. In this study, 48-h old broth cultures were used as inoculum at a population density of approx. $1 \times 10^{8} \mathrm{cfu} / \mathrm{ml}$. The inoculum $(0.20 \mathrm{~L})$ was added to the reservoirs containing $30.4 \mathrm{~L}$ of a modified half Hoagland's plant nutrient solution at 28 days after the start of the experiment Results indicate that percent total nitrogen in sweetpotato foliage tended to be higher for the inoculated fibrous mat than in the fibrous mat for non-inoculated plants. The percent total nitrogen in storage roots for the noninoculated treatment tended to be higher than in storage roots for inoculated plants. Inoculation resulted in a slight increase in foliar phosphorus concentration but had no effect on phosphorus concentration in sweetpotato storage and fibrous root samples. Inoculation tended to reduce foliar calcium concentration. Magnesium concentration in leaf tissue was not influenced by inoculation. Foliar potassium concentration tended to increase slightly. The effect of inoculation on potassium concentration in sweetpotato root tissue was not well-defined; potassium concentration tended to be higher in fibrous root tissue for the inoculated treatment. But in storage root tissue, potassium concentration was higher for the non-inoculated treatment than for the inoculated treatment. Inoculation did not affect foliar concentrations of any of the micronutrients measured. This study indicates no effect of inoculation on ionic strength of nutrients in solution reservoirs.

ECONOMIC ANALYSIS OF DIFFERENT HARVEST METHODS FOR FRESH MARKET COLLARD GREENS

Paul W. Teague* and Tina Gray Teague, Arkansas State

University, State University, AR 72467 spring field trials conducted over 2 years were used to determine differences in net returns using "cut" (harvested by removing the whole plant near the ground level for a one time over harvest) and "shucked" collards (harvested by removing marketable sized individual leaves using multiple harvests). 'Blue Max' transplants were set 11 March 1991 and 11 Feb 1992 in rows spaced $25.4 \mathrm{~cm}$ apart on raised beds spaced $1 \mathrm{~m}$ apart. Four spacing treatments were evaluated (7.62, $15.24,22.86$, and $30.48 \mathrm{~cm}$ between plants) in a RCB with 4 replications. Plants were harvested beginning 25 April 1991 and 28 April 1992 once (cut) or over 5 wks (shucked). Yields 
were higher for shucked collards spaced $15.24 \mathrm{~cm}$ in both years, but no differences Were observed in cut collards. cut collards provided a higher 1st harvest yield. A system analysis to provide 1000 boxes $(9.1 \mathrm{~kg})$ of collards/wk was imposed to determine the economics of harvest method. Cost differences Were considered to reflect differences in hectareage required, transplant cost for 4 densities, and a $25 \%$ higher harvest cost/box for shucked collards. The shuck harvest method provided an economic advantage over cutting of $\$ 9853$ and $\$ 1671$ in 1991 and 1992 , respectively, where all $\$ 9853$ and $\$ 1671$ in 1991 and 1992, respectively, where all
production was assumed to come from transplanted collards. production was assumed to come from transplanted collards.

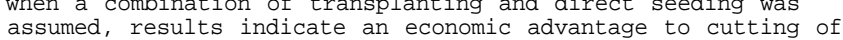
assumed, results indicate an economic advant
$\$ 680$ for the system using 1992 yield data.

\section{NITROGEN LEVEL AND LIGHT INTENSITY CAN EFFECT VEGETABLE AMARANTH LEAF NUTRIENTS}

D.J. Makus*, USDA-ARS, Booneville, AR 72927 Three-week-old transplants of Amaranthus tricolor cultivars 'RRC 241' (RC) and 'Hinn Choy' (HC) were given split applications of supplemental $\mathrm{N}$ of 0 , 100 and $200 \mathrm{~kg} / \mathrm{ha}$ and in the 5 th week after sowing were exposed to 100,70 and $50 \%$ of ambient solar radiation for nine and ten days, respectively. Increased shading had a linear (L) effect on leaf blade $\mathrm{NO}_{3}$, protein, $\mathrm{K}, \mathrm{Mg}, \mathrm{S}, \mathrm{P}, \mathrm{Al}, \mathrm{Fe}$ and $\mathrm{Cu}$ (dry wt basis). There were $L$ and quadratic (Q) increases in chlorophyll (chloro) and carotenoids. Increasing supplemental $\mathrm{N}$ increased leaf blade protein $(\mathrm{L}, \mathrm{Q})$, $\mathrm{Na}(\mathrm{L}), \mathrm{Mn}(\mathrm{L})$, chloro $(\mathrm{L}, Q)$, carotenoids $(\mathrm{L}, \mathrm{Q})$, but decreased $\mathrm{Mg}(\mathrm{L}), \mathrm{P}(\mathrm{L}, \mathrm{Q})$ and $\mathrm{Zn}(\mathrm{L}, \mathrm{Q})$. Nitrate levels showed $L$ and $Q$ increases in $R C$ and $\mathrm{HC}$, respectively. HC was higher in leaf blade $\mathrm{K}$, $\mathrm{Mg}, \mathrm{Na}, \mathrm{Fe}, \mathrm{Zn}, \mathrm{Cu}, \mathrm{NO}_{3}$, chloro and carotenoides, but lower in CA than RC. Shading had no effect on leaf area or plant fresh wt, but decreased plant dry wt while increasing plant water content. Nitrogen application increased stem length, and plant fresh and dry wt.

\section{SPINACH MANAGEMENT INFLUENCES WHITE RUST, CHLOROSIS,} ROOT GROWTH AND YIELD

Daniel I. Leskovar* and Mark C. Black, Texas A\&M University Agricultural Research and Extension Center, Uvalde, TX 78801 Effects of spinach crop management strategies on white rust (Albugo occidentalis), leaf chlorosis, root growth and yield were evaluated in winter 1991/92. Irrigation main plots were low (I-low), medium (I-med) and high (I-high). Fungicide split-plots were none $\left(F_{0}\right)$, metalaxyl at planting $\left(F_{1}\right)$, and metalaxyl at planting plus experimental CGA 2014 foliar $\left(F_{2}\right)$. Genotype split-split-plots were ACX 5044 and ARK 88-354. The Gompertz model best described the white rust disease progress. At all irrigation levels, ACX 5044 had the higher rate of disease increase $\left(r_{c}\right)$ and earlier disease onset than ARK 88-354. Metalaxyl delayed disease onset and $r_{\text {in }}$ ACX 5044 only at I-low and I-med, but not at I-high. ARK 88-354 was the least sensitive to fungicides. Yellowness and chlorosis, estimated by spectrophotometric measurements, were higher at I-med and I-high, and with $\mathrm{F}_{0}$, while ARK 88-354 had less chlorosis than ACX 5044. Root diameter was increased with $F_{1}$ compared to $F_{0}$. Lateral and tap root fresh and dry weights were higher for ARK 88-354. Yields for ARK 88-354 were significantly higher than ACX 5044. No treatments influenced the number of live or aphids parasitized by Pandora neoaphidis.

\section{A COMPARATIVE STUDY OF HYDROPONIC SYSTEMS FOR GROWING} PEANUT

A.A. Trotman*, C.E. Mortley, D.G. Mortley, P.P. David and P.A. Loretan, Tuskegee University NASA CELSS Center. Carver Agricultural Experiment Station. Tuskegee., Al 36088

Hydroponic growing systems have the potential to maximize phytomass production of peanut (Arachis hypogea) for Controlled Ecological Life Support Systems (CELSS).Two greenhouse experiments were conducted with plant nutrients supplied in a modified Evan's solutionusing a nutrient film technique. The objective of this research was to determine the effect of hydroponic growing systems on pod and foliage yield of 'New Improved Spanish' and 'Georgia Red' peanut. Sub-objectives were to evaluate (i) the impact of channel size and (ii) the impact of gradation in pore size on the separation of the rooting zone from the zone of gynophore development. The treatments consisted in the first experiment of a wide channel $(122$ by 15 by $46 \mathrm{~cm})$ fitted with a perforated $(3.0 \mathrm{~mm}$ diam.) PVC grid; a narrow channel $(122$ by 15 by $15 \mathrm{~cm}$ )either fitted with a perforated grid or without a grid. For 'New Improved Spanish' peanut dry foliage yield tended to be higher in the wide channel treatment $(0.33 \mathrm{~kg} / \mathrm{sq} \mathrm{m})$. But the narrow channel yielded the highest mean pod dry weight $(0.12 \mathrm{~kg} / \mathrm{sq} \mathrm{m})$. Pore sizes of the screens ranged from infinity (no screen). perforated grid, square mesh. filtering screen (75u) and solid screen (no pores). For 'Georgia Red' peanut, the impact of gradation in pore size of screens was variable: pod number was highest with the filtering (food) screen $(216 / \mathrm{sq} \mathrm{m}$ ) but pod dry weight was highest for the square mesh treatment $(0.09 \mathrm{~kg} / \mathrm{sq} \mathrm{m})$. Foliage yield was significantly greater for the filtering (food) screen $(1.12 \mathrm{~kg} / \mathrm{sq} \mathrm{m})$ than in any of the other treatments. The findings of the research indicate that use of screens is feasible and will not retard pod development. The presence of a perforated grid tended to result in lower phytomass production for 'New Improved Spanish' peanut.

PHOTOPERIOD/LIGHT INTENSITY INTERACTIONS ON GROWTH OF TWO SWEETPOTATO CULTIVARS IN NFT

S. Burrell*, D. Mortley, P. Loretan, L. Garner, A. Trotman, and P. David, G. W. Carver Ag. Expt. Station, Tuskegee University, Tuskegee AL 36088

The effects of photoperiod and light intensity on two sweetpotato cultivars [Ipomoea batatas (L.) Lam] were evaluated in growth chambers. Vine cuttings of 'TI-155' and 'GA Jet' were grown using nutrient film technique (NFT) in a modified half Hoaglands solution with a $1: 2.4$ $\mathrm{N}: \mathrm{K}$ ratio in channels $(0.15 \times 0.15 \times 1.2 \mathrm{~m})$. Plants were exposed to $9: 600$ or $18: 300$ umols $\mathrm{m}^{-2} \mathrm{~s}^{-1}$ photoperiod:light intensity treatments in a randomized complete block design with two replications. Temperature was set at $28: 22$ light:dark and RH was $70 \%$. Storage root fresh and dry weights and fibrous root dry weight for both cultivars were significantly higher for plants exposed to longer photoperiod and lower light intensity than for those at a shorter photoperiod and higher light intensity. Foliage fresh weight for TI-155' was higher at 18:300 photoperiod:light intensity but dry weights were similar. Foliage fresh and dry weights for 'GA Jet' and number of storagage roots/plant for both cultivars were similar regardless of treatments.

GROWTH ANALYSIS OF FIVE SWEETPOTATO (IPOMOEA BATATAS L) CULTIVARS

Victor A Khan, C. Stevens. T. Mafolo, C. Bonsi, J.Y. Lu, E.G. Rhoden, M. A.Wilson, M. K. Kabwe and Y. Adeyeye Dept. Plant \& Soil Science Tuskegee Univ. Tuskegee AL. 36088 .

TU-82-155 and 'Georgia-Jet' early maturing. 'Carver II'. TU-1892 and 'Rojo-Blanco' late maturing sweepotato cultivars were evaluated in the field for: leaf area index (LAI), net assimilation rate, foliage crop growth rate (FCGR), storage roots crop growth rate (RCGR) and alpha a (the mean relative growth rate in dry wt to the mean relative growth rate in leaf area over a time interval) or the partitioning of assimilates. A split plot design was used and plant were sampled at $6,8,11$ and $16 \mathrm{wk}$ after transplanting. The results from study showed that LAI reached maximum development 8 and $12 \mathrm{wk}$ after transplanting for early and late maturing cultivars, respectively. All cultivars irrespective to maturity groups showed a reduction in net assimilation rate $6 \mathrm{wk}$ after transplanting while FCGR for early maturing cultivars gradually declined 6 wk after transplanting and varied among late maturing cultivars. 'Carver II' showed declined 6 wk after transplanting and varied among late maturing cultivars. 'Carver II showe' and TU-1892 began to decline 8 and 6 wk after transplanting, respectively. RCGR showed rapid increases $\left(100 \mathrm{~g} . \mathrm{m}^{2} /\right.$ area/week $)$ and $\left(150 \mathrm{~g} / \mathrm{m}^{2} / \mathrm{area} / \mathrm{week}\right)$ for early and late maturing cultivars beginning $6 \mathrm{wk}$ after transplanting and this increase continued until the 12th and 8 th wk after transplanting for early and late maturing cultivars, respectively. Cultivars from both maturity groups began to produce surplus assimilates (Alpha a) $6 \mathrm{wk}$ after transplanting. which coincided with the rapid increases in RCGR at the same time. Thus indicating that storage root enlargement begins after the plant had accumulated a surplus of assimilates.

SWEETPOTATO GROWTH AND YIELD IN NFT AS AFFECTED BY TYPE OF CUTTING AND PLANTING DEPTH

Lauren Garner*, Desmond Mortley, Philip Loretan, Audrey Trotman and Pauline David, George Washington Carver Agricultural Experiment Station, Tuskegee University, Tuskegee, AL 36088

An experiment was conducted in a greenhouse environment to determine the relationship between type of cutting and planting depth on sweetpotato [Ipomea batatas (L) Lam] storage root yield using the nutrient film technique. Vine cuttings of the cultivar 'TI-155' were planted in growth channels $(122 \times 15 \times 15 \mathrm{~cm})$ in modified half Hoagland's solution. Treatments consisted of cuttings with all leaves and shoot apex removed with two nodes inserted (2NB), cuttings with all leaves and shoot apex removed with five nodes inserted (5NB). and cuttings with four leaves and the shoot apex remaining with two nodes inserted (2NB-L). Plants were harvested 130 days after planting and yield data was taken. Plants in 2NB-L had a significantly lower percent dry matter than those of 2NB. Neither cutting type nor planting depth affected yield or yield related parameters. 
EFFECTS OF BROCCOLI-CROPPED SOIL ON THE GROWTH OF BROCCOLI, CABBAGE, AND CAULIFLOWER

Jose Reynaldo A. Santos* and Daniel I. Leskovar, Texas A\&M University Agricultural Research and Extension Center, Uvalde, TX 78801

Broccoli, cabbage, and cauliflower were grown in the greenhouse on fallowed soil (FS) or on soil previously cropped with broccoli CBS) for three years. Fertilization levels (kg/ha) were none, 67N-22P, and $135 \mathrm{~N}-44 \mathrm{P}$. Inhibition of root and shoot growth components, and leaf color was evaluated at 30,44, 58, and 72 days after seeding. Shoot and root growth of cauliflower, grown on BS, progressively declined over time, while that of broccoli and cabbage either increased or remained unaffected. Application of fertilizer (67N-22P) improved the shoot growth of cabbage but did not alleviate the symptoms associated with allelopathy, i.e., stunted growth, leaf chlorosis, reduced leaf area, observed in cauliflower. Whole plant extract of broccoli decreased percent germination of cauliflower, and reduced the speed of germination of all three test crops in the order of cauliflower>broccoli>cabbage.

INDIAN MUSTARD AS A TRAP CROP FOR INSECT PESTS OF CABBAGE ON THE TEXAS HIGH PLAINS

David A. Bender*, and William P. Morrison, Texas A\&M Agricultural Research and Extension Center, Lubbock, \& 79401

Indian mustard trap crops have successfully reduced pesticide use on commercial cabbage in India. Diamondback moth has been a serious pest of cabbage in Texas and has demonstrated resistance to most classes of insecticides. Use of a trap crop could fit well in an integrated management program for cabbage insects, Three-row plots of spring and fall cabbage were surrounded by successive single-row plantings of Indian mustard in trials at Lubbock, Texas to determine the efficacy of interplanting for reducing insecticide applications. Insects in the cabbage and Indian mustard were counted twice weekly, and insecticides were applied selectively when economic thresholds were reached. Indian mustard was highly attractive to harlequin bugs, and protected intercropped spring cabbage. Cabbage plots without mustard required two insecticide applications to control the infestation. False chinch bugs were also highly attracted to Indian mustard. Lepidopterous larvae, including diamondback moth, did not appear to be attracted to the trap crop. Indian mustard trap crops reduced insecticide applications to spring cabbage but had no positive effect on fail cabbage.

\section{NITROGEN SOURCE AND TIMING EFFECTS ON YIELD AND} QUALITY OF WATERMELON

J.T. Garrett*, Pee Dee Research and Education Center, Clemson University, Route 1, Box 531, Florence, SC 29501

Nitrogen from five different sources applied preplant and sidedress to field grown watermelon (Citrullus lanatus Thunb. cv. Prince Charles) did not affect total yield but more melons were harvested earlier when potassium nitrate or calcium nitrate was applied frequently in small amounts. Conversely, two sidedressings of ammonium nitrate or soda/potash applied at 30-day intervals outperformed other application frequencies for these sources. Timing of application had little effect on earliness when sodium nitrate was the source. Improvement in percent stand was documented where total nitrogen fertilizer was applied frequently in small amounts versus infrequent larger amounts. Stand count improvements approached 30 percent for ammonium nitrate and potassium nitrate when amounts were split over five applications versus the single application. Soluble solids and flesh color were not affected by treatments used in this study.

FRUIT SET OF FALL WATERMELONS IN FLORIDA

D.N. Maynard* and G.W. Elmstrom, University of Florida, Bradenton, FL 34203

Fruit set of 'Crimson Sweet', 'Jubilee II', 'King of Hearts', 'Mickylee', and 'Sangria' watermelons was studied in Florida, In 1991 and 1992 seasons at Bradenton and Leesburg, In 1991, fruit set at Bradenton occurred primarily

from 7-10 October. At Leesburg, fruit set in at least one of the four varieties occurred over 19 days. However, there were flushes of fruit setting 25-28 September and again 5-7 October. Fruit set over the entire season ranged from 11 to $16 \%$ at Leesburg and between 17 and $20 \%$ at Bradenton. In 1992, fruit set occurred primarily between 11 and 17 october at both locations. Fruit set for the entire season ranged from 16 to $21 \%$ at Bradenton and 22 to $31 \%$ at Leesburg. The effects of bee attractants on watermelon fruit yield were studied in Manatee (Bradenton) County in fall 1991 (Bee Scent) and in Manatee and Lake (Leesburg) counties in spring 1992 (Bee-Here). Bee attractants did not significantly affect yield in three of four experiments. In the fourth experiment, early yield and average fruit weight for the entire season were increased significantly following application of the bee attractant.

GREENHOUSE TOMATOES - CULTURAL CONSIDERATIONS OF A GROWING INDUSTRY IN MISSISSIPPI

Richard G. Snyder, Truck Crops Branch Experiment Station, Cooperative Extension Service, Miissippi State University, P.O. Box 231, Crystal Springs, MS 39059.

Production of greenhouse tomatoes, while not new to Mississippi, has increased in the past 4 years to an industry of noteworthy size. This specialized industry in Mississippi has faded in and out of popularity over the years, as new growers have sometimes been stimulated by greenhouse supply companies looking for prospective customers. Often, rumors of incredibly high yields, consistently high demand and price, and minimal problems with pests and culture have encouraged novice growers to start in such a big way as to make it impossible to pay off their debts.

With strong support from the Extension Service and the Experiment Station in Missiippi, the number of grown has increased from a handful to 71 , utilizing 224 free-standing or gutter-connected greenhouse bays, occupying 12 acres under plastic. This has placed Mississippi within the top 10 greenhouse vegetable producing states in the U.S. and has helped to build a $\$ 1.8$ million industry. University support has taken the form of: 1) monthly Vegetable Press Newsletter, 2) annual Greenhouse Tomato Short Course each April, 3) Greenhouse Tomato Handbook (1992). 4) organized Greenhouse Tours. 5) a greenhouse tomato production video now in the planning stage, and 6) excellent support by Plant Pathologists and Entomologists.

To support these growers, most of whom are new to greenhouse tomatoes, a number of culturally based experiments have been performed at the Truck Crop Branch Experiment Station. These have included evaluation of heating systems, media, varieties, biological control, fog cooling, and bumblebee pollination.

\section{BACTERIAL WILT INCIDENCE IN TOMATO AS AFFECTED BY CULTIVAR AND THE DEPTH OF LIME INCORPORATION.} R. Ssonkko, S.J. Locascio, R.E. Stall, and D.N. Maynard, Horticultural Sciences Dept. and Plant Pathology Dept., University of Florida, Gainesville, FL 32611

A single lime application of $5.4 \mathrm{t} / \mathrm{ha}$ per $20 \mathrm{~cm}$ increment of soil to a depth of $60 \mathrm{~cm}$ controlled bacterial wilt (Psendomonas solanacearum E. Smith) up to 2 years in tomato (Lycopersicon esculentum Mill.) growing in a naturally infested soil. 'Sunny' with $64 \%$ disease incidence, was the most susceptible, 'Capitan' (20\%) was intermediate, and 'Caraibo' (5\%) and 'Hawaii 7997' (2\%) were the least susceptible. Incorporation of lime 40 to $60 \mathrm{~cm}$ deep reduced bacterial wilt incidence in 'Capitan' by $75 \%$, and $60 \%$ in 'Sunny'. The number of bacteria in the soil was not affected by lime treatment. Soil $\mathrm{pH}$ and total Caincreased linearly with time and with depth of lime incorporation. Bacterial wilt control in 'Sunny' and 'Capitan' was associated with an increase in $\mathrm{pH}$. Liming to 40 or $60 \mathrm{~cm}$ generally increased leaf $\mathrm{Ca}$ and decreased $\mathrm{Mn}, \mathrm{Zn}$, and $\mathrm{Cu}$. 'Hawaii 7997' contained significantly higher concentrations of $\mathrm{Ca}, \mathrm{Mg}$, and $\mathrm{K}$, and lower $\mathrm{Cu}$ compared to 'Sunny'. 'Hawaii 7997' produced significantly higher yields than the other cultivars. Deep lime incorporation increased fruit weight of 'Sunny' by $184 \%$ and 'Capitan' by $79 \%$ as compared with 0 lime.

\section{LODGING IN DIRECT SEEDED PEPPERS}

M. D. McCullough*, J. E. Motes, B. A. Kahn, N. E. Maness, Department of Horticulture and Landscape Architecture, Oklahoma State University, Stillwater, OK 74078

One of the problems associated with machine harvesting of spice peppers (Capsicum annuum L.) is plant lodging. Factorial combinations of four bedding treatments and two $\mathrm{N}$ rates were compared for effects on lodging and fruit yield of Chile at Fort Cobb and Bixby, Okla.. and of paprika at Bixby, Okla. Bedding treatments were: 1) no-bed; 2) no-bed with $5 \mathrm{~cm}$ of soil hilled to the bases of plants; 3) bedded preplant but bed not maintained throughout the growing season; and 4) bedded preplant and bed 
maintained throughout the growing season. All plots received preplant $\mathrm{N}$ at a low rate $\left(45 \mathrm{~kg} \mathrm{ha}^{-1}\right)$. Half the plots also received a topdressing of 45 $\mathrm{kg}$ ha" of $\mathrm{N}$ at early fruit set. No significant differences were found among the different bedding treatments for lodging. Bedding treatments one and three led to higher Chile yields at Bixby than treatments two and four Bedding treatments one and two led to higher paprika yields than treatments three and four. Chiles showed an increase in plant height and width with the higher $\mathrm{N}$ rate at both locations. The higher $\mathrm{N}$ rate also increased plant dry matter and fruit yield in all three studies. Paprika uprooting force was greater in treatments two and four compared to treatments one and three.

\section{ENHANCING HOT PEPPER PRODUCTION AND UTILIZATION IN MISSISSIPPI.}

Patrick Igbokwe*, June Tartt, and Robert Leard, Alcorn State University, Lorman, Mississippi 39096

Two field experiments were used to determine the vield potential of 'Long Pod' cayenne hot peppers due to foliar application of $528 \mathrm{ppm}$ each of chlormequat chloride. ethephon, and ancymidol. Applications were either made at bud formation, fruit development or fruit ripening periods. At last harvest, samples of marketable red-ripe fruits from the border rows of both 'Long Pod' cayenne and "Oriental-1" hot pepper plots were used for hot pepper sauce formulations. Two sets of 32 panelists each, were used to evaluate both the newly formulated experimental (ICES-1 and EHS-2) and commercial (CHS-1 and CHS-2) hot peppers sauces for quality. In 1990, marketable yield was highest due to chlormequat chloride. and for application made at fruit ripening. In 1991, marketable yield was highest due to ancymidol application, and for application made at fruit ripening. Mean sensory scores for hot sauce appearance, flavor and texture were generally highest for experimental hot sauces, whereas pungency scores were highest due to "CHS-1" commercial hot sauce.

\section{THE EFFECT OF SPACING ON FRUIT LOAD DISTRIBUTION ON} GREENHOUSE TOMATOES

Benjamin G. Mullinix*, Sharad C. Phatak and Janet Cooper, Departments of Statistical and Computer Services, and Horticulture, University of Georgia Coastal Plain Experiment Station, Tifton GA 317930748

Ten tomato cultivars (fresh market) were grown in a greenhouse using $30 \mathrm{~cm}$ or $45 \mathrm{~cm}$ in-row spacing with rows spaced $60 \mathrm{~cm}$ apart in 1979 from January through June. The cultivars were Big-o, Bigset, Hotset, Monte Carlo, Petra, Stella, Supal, Tropic, Wilters Villmarie, and WW200. Cultivars producing high number of fruit had lower fruit weight. Seven cultivars produced more fruit under the $30 \mathrm{~cm}$ spacing. Six cultivars produced slightly heavier fruit at $45 \mathrm{~cm}$ spacing and five cultivars produced larger class sized fruit at $45 \mathrm{~cm}$ spacing. Five cultivars had fruit by cluster distribution significantly higher up the plant at $45 \mathrm{~cm}$ spacing, while two were significantly lower. Three cultivars had greater production later in the growing period at $45 \mathrm{~cm}$ spacing, while two were greater at the beginning.

CHROMOSOME DOUBLING OF Allium fistulosum $\mathrm{x}$ A. cepa INTERSPECIFIC F HYBRIDS THROUGH COLCHICINE TREATMENT OF REGENERATING CALLUS

Ping Song*, Wanhee Kang, Ellen B. Peffley, Department of Agronomy, Horticulture, and Entomology, Texas Tech University, Lubbock, TX 79409-2122

Regenerating calli of Allium fistulosum $\times$ A. cepa interspecific $\mathrm{F}_{1}$ hybrids were treated in vitro with colchicine. A factorial experiment (colchicine concentration $x$ time) was used to recover tetraploids from calli treated with colchicine in vitro. Shoot production of regenerating calli following in vitro colchicine treatment decreased with increasing colchicine concentration and treatment time. Cytological analyses of root tip cells from regenerated plantlets showed that chromosomes of control plantlets (not treated with colchicine) were not doubled. Chromosomes of some plantlets regenerated from in vitro colchicine treated calli were doubled, resulting in tetraploids. Calli treated with 0.1 or $0.2 \frac{\circ}{6}$ colchicine in BDS (Dunstan \& Short, 1977) liquid medium for 48 or 72 hours yielded the highest number of tetraploid plantlets. These results demonstrate that in vitro colchicine treatment of regenerating calli of interspecific $F_{1}$ hybrids is effective in recovering tetraploids.

\section{INHERITANCE OF ISOZYMES: DESCRIPTION OF NEW LOCI IN ONIONS ISOZYMES}

Paul D. Mangum* and Ellen B. Peffley, Department of Agronomy, Horticulture, and Entomology, Texas Tech University, Lubbock, TX 79409-2122

Horizontal starch gel electrophoresis was used to study the mode of inheritance of isozyme phenotypes of four enzyme systems ( $\mathrm{ADH}, 6-\mathrm{PGDH}, \mathrm{PGM}$, and $\mathrm{SKDH})$ in Allium cepa L. and A. fistulosum L. by monitoring segregations in backcross and $F_{2}$ progeny. Segregation for most of the polymorphisms fit the expected Mendelian ratios as tested by the chi-square statistic. Three new isozyme loci were defined for onion. 6phosphogluconate dehydrogenase was dimeric in structure, with two alleles present at the first locus, while a second locus was monomorphic. Shikimate dehydrogenase was monomeric with two alleles.

\section{A SEASON EXTENSION TECHNIQUE FOR COOL SEASON VEGETABLES USING} POLY TUNNELS AND ROW COVERS

Gloria McIntosh* and Gerald Klingaman, Department of Horticulture and Forestry, University of Arkansas, Fayetteville, AR 72701

Spunbonded polyester or polystyrene row covers were used as additional cold protection for spinach (Spinacia oleracea), kale (Brassica oleracea), pak choi (Brassica rapa) and P-types of lettuce (Lactuca savita) grown in ground beds under unheated polyethylene tunnels during the fall and winter of 1991 and 1992 in climatic zone 6 . Temperatures inside poly tunnels averaged $2.4 \mathrm{C}$ warmer than outside. Average temperatures were $1.9 \mathrm{C}$ warmer than control under polystyrene and $1.5 \mathrm{C}$ warmer under spunbonded polyester. Average hourly temperatures showed both row covers offered significantly more cold protection than the greenhouse covering alone; but the two row covers offered similar protection from the cold. Row covers did not result in fresh weight differences in most of the species tested, except kale which had greater fresh weight in control. It may be concluded that during a similar mild winter, these cool season vegetables could be grown under unheated polyethylene tunnels with no additional protection necessary. When temperatures are lower, row covers could provide the protection required to produce these crops.

CALCIUM AND ETHEPHON EFFECTS ON PAPRIKA PEPPER FRUIT RETENTION AND FRUIT COLOR DEVELOPMENT

James R. Cooksey*, Brian A. Kahn, and James E. Motes, Department of Horticulture and Landscape Architecture. Oklahoma State University, Stillwater, OK 74078-0511

While ethephon [(2-chloroethyl) phosphonic acid] has increased yields of red fruits, its use as a pepper (Capsicum annuum L.) fruit ripening agent has been limited by premature fruit abscission and defoliation. We tested ethephon solutions of $0,1500,3000,4500$, and $6000 \mu l \cdot$ liter $^{-1}$ with or without $0.1 \mathrm{M} \mathrm{Ca}(\mathrm{OH})_{2}$ as a one-time foliar application to field-grown paprika pepper in southwestern Oklahoma. There was a linear increase in fruit abscission with increasing ethephon rates in two out of three years, with or without added calcium. Ethephon at $6000 \mu \mathrm{l} \cdot$ liter $^{-1}$ improved the percent of total fruit weight due lo marketable fruits in two out of three years, primarily by decreasing the weight of harvested green fruits. However, ethephon never significantly increased the dry weight of harvested marketable fruits over that obtained from the control. There also was no effect of ethephon on the intensity of red pigment extracted from dehydrated marketable fruits The only significant effect of $\mathrm{Ca}(\mathrm{OH})_{2}$ was an undesirable increase in the retention of green fruits on the plants. Ethephon had little value as a fruit ripening agent for paprika under the conditions of our studies, and $\mathrm{Ca}(\mathrm{OH})_{2}$ was not useful as an additive to ethephon sprays. 
EVALUATION OF CLOMAZONE FOR USE IN CUCURBITS

Wayne C. Porter*, Louisiana State University Agricultural

Center, Louisiana Agricultural Experiment Station,

Hammond Research Station, Hammond, LA 70403.

Clomazone was evaluated for reemergence weed

control in summer squash, watermelon, cantaloupe,

cucumber, and pumpkin. Clomazone was applied preplant

incorporated or surface-applied after planting. All

crops exhibited varying degrees of chlorosis in the

cotyledonary stage and first one to three true leaves.

Cucurbit tolerance to clomazone was pumpkin = squash $>$

cucumber $>$ watermelon $>$ cantaloupe. Method of

application did not affect crop vigor. Some pumpkin cultivars were more tolerant than others. Clomazone controlled Brachiaria platyphylla and Portulaca oleracea with both methods of application. Surface application provided better control of Amaranthus hybridus and $A$. spinosa. Mollugo verticillata was not controlled. Preplant incorporated application of clomazone tended to reduce the yield of watermelon.

\section{IN VITRO PRODUCTION OF SET FROM ONION (Allium cepa L.)} INFLORESCENCE.

Mohamed-Yasseen, Y.* T. L. Davenport, W. E. Splittstoesser ${ }^{2}$ and R. M. Skirvin', University of Florida, TREC, 18905 SW 280 St. Homestead, FL 33031. 'University of Illinois, Dept. of Horticulture, 1103 W. Dorner Dr., Urbana, IL 61801 Bulb formation in vitro is considered to be advantageous over shoot formation. Bulbs were farmed in vitro from onion inflorescence explants cultured in bulb induction medium composed of Murashige and Skoog (MS) medium supplemented with $120 \mathrm{~g} / \mathrm{l}$ sucrose and $5 \mathrm{~g} / 1$ activated charcoal under long day photoperiod. Bulbs were also induced in the same medium from shoots which were first regenerated from onion inflorescences in MS alone or MS containing either 4.4 uM benzyladenine or $0.005,0.01,0.05,010.1 \mathrm{uM}$ of thidiazurone. This system of in vitro bulb formation obviates shoot elongation, rooting, and acclimatization steps normally required when shoots are regenerated.

INFLUENCE OF CROP COVERS ON YIELD OF *FRITO-LAY 795' AND 'ATLANTIC' POTATOES IN MISSOURI

Hack A. Wilson*, Department of Agriculture, Southeast Missouri State 'University, Cape Girardeau,' MO 63701 and Victor A. Khan and Clauzeil Stevens, George Washington Carver Agriculture Experiment Station, Tuskegee University,

A field study, was conducted on two cultivars of potatoes ('Atlantic' and 'Frito-Lay 795') on four row covers (clear and white slitted, Vispore and spunbonded polyester) at Charleston, Missouri.. There were significant at Charleston, Missouri.. There were significant interactions in the sub-plot (row covers $x$ varieties) and sub-subplot (varieties $x$ flower treatments) for grade numbers of potatoes. Total numbers of potatoes for 'Atlantic' and 'Frito-Lay $795^{\prime}$ ' cultivars as influenced by flower removal and row cover treatments showed significant interactions of row covers $x$ varieties and varieties $x$ flower treatmants. Yield of cwt/acre of grade A potatoes for both cultivars as influenced by flower removal and row cover treatments showed a significant interaction between row covers $\mathrm{x}$ varieties. There are genetic differences among potato cultivars in response to flower removal. Cultivar response to row covers were also different based on genetic makeup. Clear and spunbonded polyester were superior to other types of row covers for grade A numbers and yield of potatoes.

SOMATIC EMBRYOGENESIS FROM LEAF OF WITLOOF CHICORY (Cichorium intybus L.)

Mohamed-Yasseen, Y.*, T. L. Davenport, W. E. Splittstoesser ${ }^{1}$, and R. M. Skirvin, University of Florida, TREC, 18905 SW 280 St. Homestead, FL 33031. ${ }^{1}$ University of Illinois, Dept. of Horticulture, 1103 W. Dorner Dr., Urbana, IL 61801

A method for regeneration of somatic embryogenesis from witloof chicory is described. Explants were taken from leaf veins of stored witloof chicory. Internal bacterial

infection was found in $100 \%$ of the leaf bases but decreased gradually toward the leaf tips. Bacterial free explants were taken from the distal third and cultured on Murashige and Skoog medium (MS) containing 1.3 uM 2,4-D, 1.3 uM kinetin, and $100 \mathrm{mg} / \mathrm{L}$ casein hydrolysate. A pale yellowish, nodular callus formed after 4 weeks and were maintained in the same medium for 8-12 months with one change to a fresh medium every 4 weeks. Callus were suspended in the same medium without agar for 4-6 weeks with one change to a fresh medium every 2 weeks. Embryo-like structure appeared upon transfer to MS liquid medium containing 1.8 uM benzyladenine. Embryo germination was accomplished in $1 / 4$ strength of MS medium with 01 without $1 \mathrm{~g} / \mathrm{L}$ activated charcoal.
INFLUENCE OF 'CRIMSON SWEET' WATERMELON WITH VISPORE ROW COVER IN COMBINATION WITH WAVELENGTH SELECTIVE MULCHES

Mack A. Wilson*, Department of Agriculture, Southeast Missouri State University, Cape Girardeau, MO 63701 and Victor A. Khan and Clauzell Stevens, George Washington Carver Agriculture Experiment Station, Tuskegee University, AL 36088.

Several plastic mulches [clear, black, IRT-76 (green), and ALOR (brown)] were used in combination with four row covers [(clear and white slitted), spunbonded polyester and VisPore]. The total numbers and marketable numbers per $1000 /$ ha were highest with the clear and IRT-76 mulches without the use of row covers, respectively. There was a significant orthagonal comparison interaction with the clear \& IRT-76 mulches vs. black \& ALOR mulches. A significant orthogonal comparison interaction was observed with total yield with row covers vs. no row cover, mulch vs. control, clear and IRT-76 vs. black \& ALOR, clear vs. IRT-76, and black vs. ALOR. Marketable yield showed a significant interaction with orthogonal comparison with row covers vs. no row cover and clear \& IRT-76 vs. black \& ALOR.

\section{SENESCENCE IN SWEETCORN}

Vincent Russo* and Aristotel Pappelis, USDA/ARS, SCARL, Lane, OK 74555; Plant Biology, Southern Illinois Univ., Carbondale, IL 62901 Fungi can colonize senescent sweet corn (Zea mays var. rugosa Bonaf.) tissue. Senescence levels of tissues can be rated. Effects of four planting dates on senescence of standard (su, cv. Merit), and supersweet (sh2, cv. Florida Staysweet) corn at fresh market and seed harvest were determined. Stalk senescence was affected by cultivar (sh2 < su) and planting date (earliest was lowest). Shank senescence was affected by cultivar (fresh market $<$ seed harvest) and planting date (lowest for plants of the earliest and latest plantings). Cob senescence was not affected by cultivar, slightly lower at fresh market than seed harvest, and lower for plants of the later than earlier planting dates. In a second experiment senescence was rated during development of sh2 cultivars. Formation of reproductive structures increased senescence rate. Cultivar had little effect on stalk and cob senescence at fresh market harvest. The cv. 'Honey'n Pearl' had the lowest shank senescence rating. Delayed senescence should be incorporated in to corn genotypes.

\section{EXPERIMENTSTO ESTABLISH KIWANO (CUCUMIS METULIFERUS} L.) AS A SPECIAL TY CROP FOR MISSOURI

Dyremple B. Marsh* and Steve Maledy Department of Agriculture, Lincoln University, Jefferson City, MO 65102

Efforts to produce specialty crops by Missouri farmers have been met with varying success. This success is reduced by the lack of established cultural practices necessary for the economic production of these crops. Ten kiwano plant introductions obtained from the Central Regional Plant Introduction Station in Ames, Iowa, were planted in the greenhouse. Seedling vigor was determined by shoot length, shoot dry weight, and number of leaves produced. Uniform seedlings from each accession were transplanted in the field with within row spacings of $0.9 \mathrm{~m}$ and $1.3 \mathrm{~m}$. Seedling vigor varied significantly between accessions. Yields of field grown kiwano were affected by plant spacing, with the closer spaced plants having the higher yields. Plant spacing had no effect on fruit color, fruit length, or fruit width. Incidents of fusarium wilt were prevalent at both plant spacings.

EFFECT OF FOLIAGE REMOVAL FOR USE AS A GREEN VEGETABLE ON GROWTH OF GEORGIA RED PEANUTS

D. G. Mortley*, J. Y. Lu, and P. Grant, G. W. Carver Ag. Expt. Station, Tuskegee University, Tuskegee AL 36088 The effect of periodic removal of peanut foliage for use as a green vegetable on final foliage and nut production was evaluated in a field experiment in the summer of 1992. Georgia Red peanut cultivar was grown in Norfolk sandy loam soil in a randomized complete block design with four replications. Treatments consisted of removing peanut foliage at 2, 4, and 6 weeks, starting six weeks after planting, and an untreated check. Fresh foliage yield declined an average of $30 \%$ while dry weight declined $34 \%$ when harvested at 2 and 4 weeks. Nut yield declined 33\% when harvested at 2 and 4 weeks but yield decreased only $10 \%$ when harvested at 6 weeks. Peanut greens are highly nutritious especially as a rich source of vitamin $C$ and protein. For good balance between foliage and nut production, it appears that harvest intervals should be after four weeks. 
USE OF OF BLACK PLASTIC MULCH AND ROW COVERS AS A METHOD OF INDUCING RESISTANCE OF LEAF SPOT DISEASES OF VEGETABLES

C. Stevens*, V.A. Khan, M.A. Wilson, D. Ploper, P. Backman, J.E. Brown, R. Rodriguez Kabana Dept. Plant \& Soil Science Tuskegee Univ. Tuskegee Inst. AL. 36088. Dept. Plant Pathology Auburn Univ., Auburn AL. 36849. Dept Hort. Auburn Univ. Auburn AL. 36849. Dept Agri. Southeast Missouri State Univ. Cape Girardeau, MO. 63701

The application of plastic mulches, row cover or a combination of the two were evaluated from 1987 to 1991 for reducing early blight of tomatoes and Alternaria leaf spot of okra. Early blight on early season tomatoes (TU-80-130, New Yorker and Floradade) was significantly reduced by the application of black plastic mulch (BM) or BM plus spunbonded polyester row cover (RC) compared to bare soil. Early blight evaluation of late season tomato (Better Boy) showed that BM significantly reduced the incidence and number of lesions per lea on the fruit clusters compared to bare soil, but the spunbonded polyester RC treatment didn't

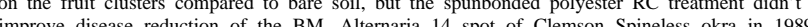
improve disease reduction of the BM. Alternaria 14 spot of Clemson Spineless okra in 1989 was severe on plant grown in bare soil compared to those grown on BM, BM plus VisPore row cover, clear plastic mulch (CM) and CM plus VisPore RC treatments. These soldier indicted that the application of agriplastic techniques could be used as a new crop management option in an IPM program to reduce the application of foliar fungicides or application of biological
control agents.

USE OF RANDOM AMPLIFIED POLYMORPHIC DNA (RAPD) TO IDENTIFY SHORT-DAY GRANO-TYPE ONION CULTIVARS

Virginia P. Roxas and Ellen B.Peffley*, Department of Agronomy, Horticulture, and Entomology, TexasTech University, Lubbock, TX 79409-2122

Nineteen random primers yielded 36 PCR-amplified products

of Allium cepa profiles of each of 15 short-day granotype onionsgrown commercially in Texas and Southern United States were compared. Several PCR productswere unique among the cultivars and can be used to differentiate among the onion cultivars investigated. A phenogram of the cultivars based on the co-occurrences of the PCR products was derived.

\section{Floriculture \& Ornamentals}

PERENNIAL GARDEN ASTER PRODUCTION IN NORTHWEST ARKANSAS

Lynn Goff*, Alfred Einert and Gerald Klineaman, Department of Horticulture and Forestry, university of Arkansas, Fayetteville, AR 72701

Success of European research and marketing efforts on perennial garden asters prompted American nurserymen to introduce (Aster novi-belgii and Aster ericoides) for fall bedding plant sales in the United States. This research investigated the feasibility of asters for outdoor production in Northwest, AR. and examined general cultural practices for growing asters in this region. Variety, fertilization and pruning trials with 15 cultivars of perennial aster were conducted at Fayetteville, AR. in 1992. Six varieties demonstrated retail market potential based on appearance and growth habit. Plants produced from rooted cuttings established 6 June in 3.78-liter containers were of high market quality in 8-12 weeks. A conventional resin-coated slow release fertilizer plus $500 \mathrm{ppm} \mathrm{N}$ weekly or conventional slow release product plus 180 ppm N constant feed, produced better growth than the slow release fertilizer used alone. of 9 pruning regimes, results showed a significant difference in plant height and width by treatment across varieties. The differences among treatments were consistent for each variety. Pruning had no significant effect on bloom date or duration of bloom.

Copper Hydroxide Controls Root Distribution In ContainerGrown Carpentaria Palm

Sven E. Svenson*, and Timothy K. Broschat, Fort Lauderdale Research and Education Center University of Florida - IFAS, 3205 College Avenue, Fort Lauderdale, FL 33314 The influence of copper hydroxide $\left[\mathrm{Cu}(\mathrm{OH})_{2}\right]$

application to interior container surfaces on root growth at the container-medium interface was studied using Carpentaria palm [Carpentaria acuminata (H. Wendl. Drude) Becc.]. $\mathrm{Cu}(\mathrm{OH})_{2}(0,100,200$, or $400 \mathrm{~g})$ was mixed with one liter of either white latex house paint, or NuFilm-17 surfactant, and applied to all surfaces inside 0.5 liter containers. Plants were grown in untreated containers, in containers treated with paint or NuFilm-17 only, or in containers treated with $\mathrm{Cu}(\mathrm{OH})$ in paint (100 g rate only) or NuFilm-17 (100, 200 or $400 \mathrm{~g}$ per liter). When applied in paint or NuFilm-17, $\mathrm{Cu}(\mathrm{OH})_{2}$ reduced root growth at the container-medium interface, controlling the circular growth pattern commonly observed in containergrown plants. Controlling circling root growth at the soil-container interface did not influence shoot or root dry weight, but did reduce total root length.

Application of $\mathrm{Cu}(\mathrm{OH})_{2}$ with paint was unsightly, while application with NuFilm-17 was almost unnoticeable.

INFLUENCE OF SPRING POTTING DATE AND CONTROLLED RELEASE FERTILIZER ON CONTAINER PRODUCTION OF WOODY ORNAMENTALS

D. Joseph Eakes and John W. Olive, Department of Horticulture and Ornamental Horticulture Substation, Alabama Agricultural Experiment Station, Auburn University, AL 36849

Two 8- to 9- month [Nutricote 20-7-10 (Type 270) and osmocote 18-6-121 and two 12- to 14- month [Nutricote 20-7-10 (Type 360) and Osmocote 17-7-121 controlled release fertilizers were preplant incorporated into a $3: 1$ pine bark:peat moss medium during two potting dates (April 12 and June 6,1991 ) at the rate of $1.5 \mathrm{~kg} \mathrm{~N} / \mathrm{m}^{3}$. Plant growth of two woody ornamentals, 'Green Luster' Japanese holly and 'Fashion' azalea, and monthly medium solution electrical conductivity (EC) were determined. Growth index [GI = (height + width at widest point + width perpendicular to widest point)/3] response to fertilizer treatment was species specific. Nutricote 20-7-10 (type 360) produced the largest GIs for holly, while GIs for azalea were not affected 420 days after initiation (DAI) of the test. Plants potted in April had greater GIs than those potted in June for the two plant species 420 DAI, regardless of fertilizer type. Osmocote 18-6-12 and 17-7-12 controlled release fertilizers had the greatest medium solution ECs from 90 to 180 DAI.

\section{FUNGICIDAL CONTROL OF LEAF AND STEM DISEASES ASSOCIATED WITH VINCA MINOR L.}

Mary C. Koelsch* and Janet C. Cole, Department of Horticulture and Landscape Architecture, Oklahoma State University, Stillwater, OK 74078

Vinca minor production in Oklahoma nurseries has declined in recent years due to foliar diseases. A study was conducted to determine whether several labeled and experimental fungicides control these foliar diseases in Vinca minor 'Bowles'. This study was conducted outdoors under unusually mild and humid conditions, which were conducive factors for disease symptoms to occur throughout the season. Plants were sprayed at weekly intervals with the fungicides propiconazole $(0.95$ $\mathrm{ml} /$ liter $)$, thiophanate methyl $(1.58 \mathrm{ml} /$ liter $)$, thiophanate methyl/mancozeb (1.79 g/liter), triforine (3.95 ml/liter), CC 17461 (3.95 $\mathrm{ml} /$ liter), CGA 173506 (0.47/liter), or SAN 619 (0.79 ml/liter). Thiophanate methyl/mancozeb was the most effective of all chemicals at decreasing foliar dieback; however, no chemical completely controlled the disease symptoms throughout the season. Dry weights of plants treated with thiophanate methyl/mancozeb were greater at the end of the season than those of plants receiving the other fungicidal treatments.

COMPOSTED POULTRY MANURE AS POSSIBLE FERTILIZER SOURCE FOR CONTAINER GROWN WOODY ORNAMENTALS Gerald Klingaman and G.L. Wheeler, Department of Horticulture and Forestry, University of Arkansas, Fayetteville, AR 72701

Eight species of woody nursery stock were grown in 4 liter containers and fertilized with a conventional resin-coated slow release material (at $3.5 \mathrm{~g} \mathrm{~N}$ per container) or composted poultry manure applied as a top dressed or incorporated with nitrogen rates ranging from 1.0 to $11.2 \mathrm{~g} \mathrm{~N}$ per container. In all cases the conventional resincoated product outperformed composted poultry manure by factors of 2 to 3 times (for height, dry weight and quality score). Although a rate response was observed with the composted, even the highest rate of nitrogen application produced plants with dry weights of $1 / 2$ that of the control. When comparing the sources of composted poultry manure alone, the 4-4-4 product outperformed the 2-2-2 compost, even with equivalent rates of nitrogen, for 3 of the 8 species studied. Incorporation proved superior to topdressing for the 4-4-4 source but topdressing was superior for the 2-2-2 material. These studies are part of a nutrient partitioning experiment being conducted to determine the fate of nitrogen released from composted poultry manure. 
CUT FLOWER PRODUCTION IN NORTHEAST TEXAS

Garry V. McDonald* and H. Brent Pemberton, Texas A\&M University Agricultural Research and Extension Center. P.O. Box E, Overton, Texas 75684

Cut flower production in a low-input greenhouse for winter and spring holiday sales was evaluated. Low-input structure was a plastic covered Quonset greenhouse modified with sides that could be manually raised or lowered. Sides were raised on mild days for ventilation and remained closed for minimum heating for the few brief periods of sub-freezing temperatures characteristic of the local winter climate. Bulbs of tulip (Tulipa sp L.) cultivars 'Maureen', 'Negrita', and 'Oxford' were dry cooled for 12 weeks and planted in December for Valentine's Day forcing. 30\% shading did not significantly increase stem length in 'Maureen' and 'Oxford' but did increase stem length in 'Negrita'. 'Oxford' was at a harvestable stage for the. Valentine's Day market, but not 'Maureen' or 'Negrita'. All cultivars were of an acceptable quality. Plugs of snapdragon (Antirrhinum majus) cultivars 'Appleblossom', 'Potomac white', and 'Rocket Rose' were planted in late winter at 4 and 6 inch spacing and were either pinched or not pinched. For all cultivars, pinching resulted in higher yield but lower grade. Four inch spacing had a slightly larger number of higher grade stems possibly due to stretching. 'Appleblossom' and 'Potomac White' were florist grade, whereas 'Rocket Rose' was more appropriate for mass marker For both tulip and snapdragon, cultivar evaluation is necessary to determine suitable market strategy.

\section{CONTROL OF BLACKSPOT ON ROSE WITH CYPROCONAZOLE}

W. E. Roberson*, H. B. Pemberton, and G. L. Philley, Texas A\&M University Agricultural Research and Extension Center, P.O. Box E, Overton, TX 75684

Plants of Rosa 'Mr. Lincoln' and 'Peace' were established in March 1992. Using a RCB design, fungicide treatments were initiated on 15 May and terminated on 22 Oct. 1992. Foliar applications were made with a Birchmeier ${ }^{\circledR}$ Closed System Unit equipped with a ConeJet ${ }^{\circledR} \# 5500$ adjustable spray tip at 5065 psi. Treatments were cyproconazole at $0.1,0.2$, and $0.4 \mathrm{~kg} \cdot \mathrm{ha}^{-1}$ applied at either 14 or 28 day intervals, mancozeb at $2.250 \mathrm{~g} \cdot 1^{-1}$ applied every 7 days, and an untreated control. Cyproconazole treatments were applied in $9461 \cdot$ ha $^{-1}$ water and mancozeb was sprayed to runoff. Disease pressure and plant defoliation ratings were taken on 29 June and 26 August. The disease rating was based on a scale of $1-10$, where $1=$ no infection and $10=$ severe infection and defoliation. The defoliation rating was based on a scale of $1=10$, where $1=0-10 \%$ and $10=91$ $100 \%$ defoliation of canopy. A full season control rating was determined on 17 Nov. 1992, based on a scale of 1-3, where $1=$ excellent, $2=$ acceptable, and $3=$ unacceptable control of blackspot. Blackspot control with mancozeb was unacceptable on either cultivar. Cyproconazole at $0.1 \mathrm{~kg} \cdot \mathrm{ha}^{-1}$ every 28 days did not control blackspot by mid-November with 'Peace' and was marginally acceptable on 'Mr. Lincoln'. Season long disease control was near excellent for both cultivars with $0.2 \mathrm{~kg} \cdot \mathrm{ha}^{-1}$ cyproconazole every 28 days. All other cyproconazole treatments proved to be excellent.

\section{HOME COMPOSTING: A STATE-WIDE INTERAGENCY \\ INITIATIVE}

WJ. McLaurin \& G.L. Wade, U. of Georgia, Athens, GA 306002

In response to national Cooperative. Extension Service initiative and Georgia's Solid Waste Management Acts, eight state agencies and University of Georgia personnel joined forces to demonstrate simple and effective home composting concepts in a workshop format. Attended by over 550 participants, a series of ten workshops were held in selected locations throughout the state. These workshops were designed to instruct local volunteers to teach appropriate waste management practices concerning home composting and how home composting can help meet the state mandated $25 \%$ landfill reduction goal, what costs are involved, how to establish a community education program, and where to obtain technical assistance. During the daylong workshop, participants heard presentations on five important aspects of the role of composting in community waste management--the legislative/environmental mandate., the composting process, equipment/site requirements, curbside waste reduction, and start-up for local programs in home composting.

As the first state-wide home composting educational project, it serves as a model for other state-wide initiatives targeting waste management concerns, and creates appropriate impetus for community waste management action throughout the state.

URBAN FORESTRY AND EXTENSION: A WORKING PARTNERSHIP L. Nash , W. Fountain and M. Witt*, Department of Horticulture, N-316 Ag Science North, University of Kentucky, Lexington, KY 40546-0091 In a unique partnership. the University of Kentucky Dept. of

Horticulture, the Cooperative Extension Service, and the Kentucky State Division of Forestry are teaming up to produce two training packages for "train-the-trainer" workshops throughout the state. The workshops will be open to people interested in urban/community trees and arboriculture.

The first training session will be held in 1993 and will cover five modules: 1) Designing the planting site to compensate for a disturbed environment; 2) Species selection for the existing site; 3) Scientific planting techniques; 4) Post-planting care: and 5) Integrated pest management.

The second training session will be held in 1994 and will cover the following topics: 1) Establishing a scientific management program for the urban forest; 2) Preparation and administration of grants: 3) Fund-raising and efficient use of volunteers; 4) Developing an urban tree inventory; 5) Recognition of hazard trees; and 6) Selecting quality nursery stock.

The training packages will consist of a written manual, videos, and slide sets. Training sessions are open to foresters, county agents, city planners, developers, and others in Kentucky who are interested in returning to their communities and training others on the topics covered.

\section{GROUND COVERS FOR SEMI-ARID LANDSCAPES.}

C. B. McKenney* and F. Gaitán-Gaitán, Department of Agronomy, Horticulture, and Entomology, Texas Tech University, Lubbock, Texas 79409-2122

The High Plains of Texas is a short-grass prairie with an extremely stressful environment which limits adapted ornamentals. Plant materials capable of consistent performance have yet to be established for this region. Twelve perennial ground covers were evaluated for urban landscape use. Species were planted in a completely radomized design split in time with four replicates. Ground coverage and distance of spread were evaluated monthly for two growing seasons in 1989 and 1990 . Visual ratings of quality as ground cover were also determined using color, growth and density as indices. Sedum brevifolium, Sedum acre, Lysimachia nummularia, Sedum sieboldi, and Arrhenatherum elatius 'Variegatum' were the most promising species for all criteria. Sedum acre and Arrhenatherum elatius 'Variegatum' did not perform well at temperatures above $40^{\circ} \mathrm{C}$. Sedum stolonifera failed to survive in this demanding environment.

FOUR ORNAMENTALS RELEASED FROM ARKANSAS PEACH BREEDING PROGRAM James N. Moore*, Roy C. Rom, Stanley A. Brown and Gerald L. Klingaman, Department of Horticulture and For\&try, University of Arkansas, Fayetteville, AR 72701

Three ornamental peaches and one ornamental nectarine were released in 1992 from the Arkansas peach breeding program. 'Tom Thumb' is a red-leaf dwarf peach with attractive foliage that is retained throughout summer. 'Leprechaun' is a greenleaf dwarf nectarine with small but attractive, freestone fruits. 'Crimson Cascade' and 'Pink Cascade' are red-leaf peaches with trees of standard size that exhibit a weeping growth habit. 'Crimson Cascade' produces double flowers that are dark red while 'Pink Cascade' double flowers are pink. The attractive plants of these cultivars should be of value in home landscapes.

\section{Education}

\section{ESTABLISHMENT OF THE LSU AGRICULTURAL CENTER NATIVE PLANT ARBORETUM}

Allen D. Owings*, Charles E. Johnson, and M. LeRon Robbins, Calhoun Research Station, Louisiana Agricultural Experiment Station, LSU Agricultural Center, P.O. Box 539, Calhoun, LA 71225

Educational and research opportunities utilizing native plant species are being developed by the LSU Agricultural Center through the recent establishment of a native plant arboretum at the Calhoun Research Station. Plants indigenous to Louisiana and surrounding states are being collected and planted in the arboretum for evaluation of potential values for landscaping, in food industries, and/or wildlife management. Native trees being studied include species of oak (Quercus), maple (Acer), hickory (Carya), and dogwood (Cornus). Lesser known species of holly (Ilex) and hawthorn (Crataegus), are being evaluated for commercial production and landscape potential. Fruit being collected for field orchard studies include mayhaw (Crataegus opaca), pawpaw (Asimina triloba), and several native plums (Prunus spp.). 
HORTICULTURE EDUCATION AT THE 1ST GRADE LEVEL

E.W. Bush*, A.W. Fennel, W.A. Young, T.J. Raiford; Dept. of Horticulture, Louisiana State University, Baton Rouge, LA 70803

To promote both learning and horticulture, a 5 year pilot program was implemented with a collaborative effort between the Louisiana State University Horticulture Department and the University Laboratory School. The objective of this program was to develop a hands-on approach to learning which fostered self-discovery and a positive perception of horticulture. First graders were able to experiment in both the greenhouse and in the field with instruction in the classroom. Among the many concepts that the children were Introduced to, they benefitted most from being able to participate and observe the process from seeding to harvesting enabling them to work with the different types of seeds, media, and fertilizers. In the classroom, horticulture was Integrated in every subject of the first grade class. For example, the students learned math by measuring and counting the produce then making charts to report their findings. The result of the program was that the children did in fact obtain a positive perspective of horticulture while developing an awareness of the process of growth and development of horticultural crops. The first grade class received a national award for donating their produce to the local food bank in Baton Rouge.

\section{CAD/GIS AS A TOOL IN NATIVE PLANT SPECIES} CONSERVATION

D.L. Creech* and D. McDonald, Department of Agriculture and College of Forestry, Stephen F. Austin State University, Nacogdoches, TX 75962 Texas is botanically diverse with approximately 5500 native plants identified: east Texas contains about $40 \%$ of the total. While most species are stable, many are classified as rare, threatened, vulnerable, or endangered. Databases for east Texas plant communities and vegetative analyses are numerous. However, they are not yet integrated into easyto-sort-and-query computer files. Computer-Assisted Drafting (CAD) and Geographic Information Systems (GIS) technology offers powerful applications to the storage, management, and spatial analysis of species inventories, plant community dynamics, and long-term habitat monitoring. At SFASU, the College of Forestry's GIS Center is being utilized to develop comprehensive east Texas resource inventories on a ten-station HP Apollo/ArcInfo platform. In the horticulture program, a twentystation PC/AutoCad teaching laboratory is being used to create layered maps of the SFASU Arboretum, the on-campus landscape and off-campus plant communities. The integration of $\mathrm{CAD}$ and GIS projects through a DXF format takes advantage of the attributes of both technologies.

\section{Posters}

EFFECTS OF RHIZOCTONIA SOLAM DENSITY IN POTTING SOIL ON EFFICACY OF BIOLOGICAL AND CHEMICAL TREATMENTS IN ROSEMARY PROPAGATION

Nancy E. Maness*', James E. Motes', and Kenneth E. Conway ${ }^{2}$ 'Department of Horticulture \& Landscape Architecture, ${ }^{2}$ Department of Plant Pathology, Oklahoma State University, Stillwater, OK 74078

Aerial blight of rosemary (Rosemarinus officinalis) caused by Rhizoctonia solani (AG-4) is a problem in production of rooted cuttings. Two separate studies were conducted on rosemary cuttings during propagation. Four levels of $R$. solan were mixed into potting medium at the rates of $0,0.01,0.1$ and 1.0 percent $(\mathrm{w} / \mathrm{w})$ Seven treatments were evaluated: Trichoderma harzianum alone, Laetisaria arvalis alone, iprodione (single application, full rate), CGA 173506 (single application, full rate), T. harzianum + iprodione (single application, $1 / 2 \mathrm{x}$ rate), L. arvalis + CGA 173506 (single application, $1 / 2$ rate), and a control. Biocontrol agents were mixed into medium at a rate of $5 \mathrm{~g} / \mathrm{kg}$ medium. Mycelial growth began by day four on the medium surface in the 0.1 and $1.0 R$. solani levels. By day six, cuttings showed signs of infection. Disease incidence increased with higher levels of $R$. solani inoculum. At levels $0.01,0.1$ and 1.0 , the L. arvalis plus $1 / 2 \mathrm{x}$ rate one time application CGA 173506 and iprodione alone (full rate one time application) gave the best control of aerial blight in both experiments. In the first experiment, iprodione alone and $T$. harzianum plus $1 / 2 \mathrm{x}$ rate iprodione gave the most root growth at the $0.01,0.1$ and $1.0 R$. solani levels. In the second experiment, $L$. arvalis plus $1 / 2 \mathrm{x}$ rate CGA 173506 gave best root growth. At level 0 , treatments were not significantly different in either experiment.
INFLUENCE OF PESTICIDES ON NITROGEN CONTENT OF TOMATO PLANTS

David N. Sasseville, Lincoln University, Jefferson City, MO 65101

Tomato plants were grown in a greenhouse in a sand:soil mixture with six pesticide treatments applied weekly at $1 \mathrm{mg}$ a.i./ $/ \mathrm{kg}$ soil mixture as a soil drench. Plants were grown for six weeks with nitrogen applied weekly at 80 mg per plant as calcium nitrate. Glyphosate (Roundup) was toxic to plants with reduced dry weight of all tissues, but greater nitrate concentration in the leaf and root tissues. Captan produced the greatest dry weight, with mot tissues dry weights significantly greater than the control treatment. Captan resulted in significantly higher nitrate content in the tissues, but there was no difference between captan and the control on total $\mathrm{N}$ content. Both nitrapyrin (N-Serve) and sethoxydim (Poast) had significantly less growth and total $\mathrm{N}$ content than the control, as well as higher nitrate content in the growing medium. It appears that these two chemicals may inhibit nitrate uptake or cause other phytotoxic effects The other chemicals metalaxyl (Subdue) and etridiazole (Terrazole) had intermediate responses. While they both had reduced growth and total $\mathrm{N}$ content, these were not significantly different from the control treatment. Etridiazole had reduced nitrate content, but metalaxyl nitrate content was significantly greater than the control and comparable to captan, primarily because of high nitrate content in the leaves.

LEAF ELEMENTAL CONTENT AND GROWTH OF 'SHAWNEE' BLACKBERRY AS INFLUENCED BY APPLIED K AND NA

James M. Spiers, * USDA-ARS Small Fruit Research Station, Poplarville, MS 39470

The effects of varying potassium and sodium

fertilization levels on 'Shawnee' blackberry (Rubrus, subgenus Eubatus, spp.) plant growth and leaf elemental content were studied in sand culture experiments. Increasing $K$ fertilizer levels linearly increased $\mathrm{K}$, but decreased $\mathrm{Mg}$ and $\mathrm{Zn}$ in the leaves. Concentrations of $\mathrm{Na}, \mathrm{Ca}, \mathrm{Cu} . \mathrm{Fe}$, and $\mathrm{Mn}$ were not significantly influenced by $\mathrm{K}$ fertilization. Plants contained six times more $\mathrm{Na}$ with high than with low $\mathrm{Na}$ fertilization. $\mathrm{Na}$ fertilization did not significantly affect leaf $\mathrm{K}, \mathrm{Ca}, \mathrm{Mg}, \mathrm{Fe}, \mathrm{Cu}$ or $\mathrm{Zn}$, but leaf $\mathrm{Mn}$ was linearly reduced by increasing $\mathrm{Na}$ fertilization. Leaf $\mathrm{K}$ and $\mathrm{Na}$ were directly influenced by the amounts of supplied $\mathrm{K}$ and $\mathrm{Na}$. 'Shawnee' blackberries readily take up $\mathrm{Na}$ but exhibit some salt tolerance at low to moderate $\mathrm{Na}$ fertilization levels. At high $\mathrm{Na}$ levels, they appear to lack a mechanism to reduce $\mathrm{Na}$ uptake, which results in reduced plant growth.

COTTON GIN TRASH AS A CONSTITUENT OF BEDDING PLANT MEDIA

Allen D. Owings*, Calhoun Research Station, Louisiana Agricultural Experiment Station, LSU Agricultural Center, P.O. Box 539, Calhoun, LA 71225

A greenhouse study was conducted to determine the influence of media containing varying volumetric proportions of composted cotton gin trash and pine bark on the growth of Coleus $x$ hybridus 'Golden Bedder'. All media treatments were amended with $1.5 \mathrm{lbs} / \mathrm{yd}^{3} \mathrm{Micromax}$ and $8 \mathrm{lbs} / \mathrm{yd}^{3}$ dolomite. Plant height, shoot dry weight, and visual quality ratings were determined six weeks after potting. Media composed of $100 \%$ cotton gin trash produced plants with significantly less height and shoot dry weight. Height inhibition was apparent by 3 weeks after potting. Coleus grown in media composed of 60-1002 pine bark had higher visual quality ratings than those grown in media having cotton gin trash as the primary constituent.

TEXAS POTATO GROWERS OPTIMIZE NITROGEN MANAGEMENT Roland E. Roberts* and Michael G. Hickey, Texas A \& M University Research and Extension Center, Rt. 3, Box 213AA, Lubbock, TX 79401 Texas processing potato growers want high tuber yield and soluble solids with optimal nitrogen $(\mathrm{N})$ fertilization to avoid leaching $\mathrm{N}$ into underground water. A 3-year on-farm study demonstrated petiole and soil testing methods for $\mathrm{N}$ enabling growers to apply $\mathrm{N}$ at rates and times for maximum yield with acceptable specific gravity. For example, a FL-1553 crop received $160 \mathrm{~N} \mathrm{~kg} / \mathrm{ha}$ in irrigation water spread over 126-day season. Sampling every 2 weeks from early vegetative stage to harvest showed petiole $\mathrm{N}$ of $22,000 \mathrm{ppm}$ on day $40 ; 6,000 \mathrm{ppm}$ on day $54 ; 3,000 \mathrm{ppm}$ on day 68 ; $7,000 \mathrm{ppm}$ on day 96 ; and $2,000 \mathrm{ppm}$ by day 110 . At harvest total tuber $\mathrm{N}$ $=1.12 \%$; tuber specific gravity $=1.081(17.1 \%$ FritoLay solids $)$; and processor acceptable yield $=304 \mathrm{~g} / \mathrm{ha}$. The crop removed nearly all applied $\mathrm{N}$ 
STRAW MULCH UNDER STRAWBERRIES REDUCES EROSION AND HAILDAMAGE

Julia Whitworth, Department of Horticulture, Oklahoma State University, Wes Watkins Agriculture Research and Extension Center, Land, OK 74555 In September of 1991, $1.1 \mathrm{~m}$ x $20 \mathrm{~cm}$ raised beds were built near Lane, OK. The beds were covered with straw or woven plastic mulch, or were left uncovered. Heavy rains in October left the uncovered beds about $20 \mathrm{~cm}$ wide $\mathrm{x} 13 \mathrm{~cm}$ tall. A gully was formed at the end of this field, and soil was deposited across several beds. Strawberry plants were set into all beds in mid-February 1992. At this time, the straw-mulched beds, although settled into an inverted "V" shape, were still about $1 \mathrm{~m}$ wide and about $18 \mathrm{~cm}$ tall. A very intense hail and rain storm struck the fields on May 13. Most of the hail was about $1.3 \mathrm{~cm}$ in diameter. The hail fell for about 30 minutes in early afternoon. The hail was accompanied by about $12.7 \mathrm{~cm}$ of rain. The strawberry plants on the woven plastic mulch were almost completely destroyed. The strawberry plants on bare ground were severely damaged by the hail, and their roots were often washed out of the ground. About 85 to 90 percent of these plants died. Strawberry plants on the straw-mulched beds appeared to be less damaged by the hail than other plants, and were not washed out of the ground. About $95 \%$ of these plants survived.

INFLUENCE OF SEED PREPARATION AND PLANTING DATE ON DAMPING-OFF OF WATERMELON

Melvin R. Hall*, Department of Horticulture, and Donald R. Summer, Department of Plant Pathology, University of Georgia Coastal Plain Experiment Station, Tifton GA 31793-0748 Primed, germinated, and untreated seeds of three watermelon [Citrullus lanatus (Thunb.) Matsum \& Nakai] cultivars were planted in March and April of 1990 and 1991 to evaluate damping-off incited by Pythium irregulare and Rhizoctonia solani AG-4. One week after seeding in 1990, plant stand was greater from primed and germinated than untreated seeds in noninfested soil and greater from primed than germinated or untreated seeds in soil infested with $P$. irregulare. Neither germinated nor primed seeds improved plant establishment in soil infested with $R$. solani AG-4. Early plant stand was greater from the April than the March planting in each year. Plant establishment was more consistent from 'Crimson Sweet' than 'Jubilee' or 'Charleston Gray', but cultivar differences in response to $P$. irregulare or R. Solani AG-4 were not detected. Primed watermelon Seeds may enhance stand establishment in soil infested with $P$. irregulare when soil temperature at planting is suboptimal to optimal for watermelon seed germination and growth.

\section{EVALUATION OF SOUTHERNPEA CULTIVARS FOR FRESH MARKET} MECHANICAL HARVEST

B. Buckley ${ }^{1}$, W.A. Mulkey², J.D. Griffins, K.C. Peel, T. Talbota, and W. Russell ${ }^{3}$, Calhoun Research Station, Calhoun, LA 712251, Sweet Potato Research Station, Chase, LA 71324', Louisiana Agricultural Experiment Station, LSU Agricultural Center. Louisiana Tech University, Ruston, LA 71272

Four southernpea cultivars were evaluated for fresh market mechanical harvest at Calhoun, Chase, and Ruston, Louisiana. The cultivars were 'Encore', 'Royal Cream',

'Queen Anne', and 'Texas Pinkeye'. In addition, 'Early Acre' and breeding lines AR87-435 and AR91-135 were also evaluated at Chase. The marketable yield from mechanical harvest ranged from $1075 \mathrm{~kg} \cdot \mathrm{ha}^{-1}$ for 'Royal Cream' at Calhoun and Ruston to $1855 \mathrm{~kg} \cdot \mathrm{ha}^{-1}$ for 'Encore' at Calhoun and Chase. Low concentrated maturity was the main factor limiting marketable yield. The percent mature pods at harvest was near 55 for most cultivars. Yield efficiency of mechanical harvest vS. hand harvest was above $75 \%$ for most cultivars. The percent trash resulting from machine harvest ranged from 6 for AR91-135 to 24 for 'Queen Anne'.

EFFECTS OF SEED SIZE ON LIMA BEAN GROWTH AND DEVELOPMENT Jim E. Wyatt* and Marla C. Akridge, Department of Plant and Soil Science, University of Tennessee, West Tennessee Experiment Station, Jackson, TN 38301

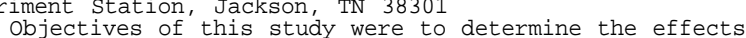
of lima bean seed size differences and a short chilling of lima bean seed size differences and a short chilling period after planting on seedling emergence rate, seedling abnormalities and vigor. Individual seeds of 'Jackson Wonder' lima bean were weighed and placed into one of five
size classes: $24-33$. 36-41. 44-49, 52-57, and 60-73 g per 100 seed. Seed of each size class were germinated at a constant
23-26C or chilled at $8 \mathrm{C}$ for $24 \mathrm{hrs}$ and then moved to $23-26 \mathrm{C}$ conditions for the remainder of the study. A $24 \mathrm{hr}$ chilling period after planting had a detrimental effect on subsequent after planting. Plant fresh and dry weights were after planting. Plant fresh and dry weights were Tignificantly less for the chilled seed treatment. Temperature treatments had no effect on percent normal and
abnormal seedlings or primary leaf area. No differences in seedling emergence number or rate were found among seed size classes. Smaller seedclasses had significantly fewer normal and more abnormal seedlings than larger seed size classes. The largest seed class produced seedlings with about two times more fresh and dry weights and leaf area than those from the smallest seed weight class. Plant fresh and dry weights and leaf areas from all seed size classes were significantly different from each other.

COMPARATIVE STUDY OF WATER ECONOMY OF CONTAINER-GROWN WOODY ORNAMENTAL SHRUBS

E.C. Boehm*, T.D. Davis and J.O. Kuti, Dept. of Agronomy and Resource Sci., Hort. Crops Research Lab., Texas A\&I University, Kingsville, Texas 78363.

Relative water usage of four species of container-grown woody ornamental shrubs (Buxus japonica (Japenese boxwood), Leucophyllum frutescens (Texas sage), Ligustrum japonica (ligustrum) and Pittosporum tobira wheeleri (dwarf) pittosporurm)), normally used for home landscaping in south Texas, were evaluated by comparing water consumption and frequency of watering with growth rates and horticultural quality after six months growth in containers. Growth rates were determined by the difference in plant height and leaf area from the control unwatered plants and were used to characterize the suitability of ornamental shrubs for xeric landscapes. While frequency of watering had no significant effects on plant height, only ligustrum and dwarf pittosporum plants watered on weekly basis showed positive change in leaf area. There was considerable leaf regrowth in Texas sage plants after initial leaf loss. Of all the shrubs tested, dwarf pittosporum plants watered biweekly used less water to maintain their horticultural quality.

ROW COVERS, WATERMELON, AND HAIL DAMAGE

Warren Roberts* and Julia Whitworth, Wes Watkins Agricultural Research \& Extension Center, Oklahoma State University, Box 128, Lane, Oklahoma 74555

A factorial experiment with four mulch treatments (clear, black, or IRT plastic, and a non-mulched control), two planting types (seed vs. transplants), and two row cover treatments (with and without) was initiated to determine the harvest date of watermelon with these treatments. Experiments were planted in the field April 7. Row covers (Kimberly Farms, spunbonded polypropylene, $20 \mathrm{~g} \cdot \mathrm{m}^{-2}$ ) were suspended on wire hoops above selected plots. Soil temperatures at $5 \mathrm{~cm}$, measured at noon, were lower in plots with row covers. On May 13, the row covers were in the process of being removed when a thunderstorm developed. One guard row remained covered during the storm. Hail ranging from 1.3 to $2.5 \mathrm{~cm}$ in diameter fell for 30 minutes, with a final accumulation of $5 \mathrm{~cm}$ of hail and $10 \mathrm{~cm}$ of rain. There was no noticeable difference between transplants and direct seeded plants, or among the different types of mulch, on resistance to hail damage. All plots that were not covered with row covers were totally destroyed. However, the area on which row covers had not been removed received only minor damage.

AIR AND MEDIA TEMPERATURE INFLUENCE GROWTH AND QUALITY OF CUT FLOWER SNAPDRAGON

Jesse R. Quarrels and Steven E. Newman. Department of Horticulture, Agricultural and Forestry Experiment Station, P.O. Drawer T, Mississippi State, MS 39762-5519.

Greenhouse studies of cut flower snapdragons (Antirrhinum majus L.) using two night air and two root-zone temperatures were conducted to determine the effects on growth and quality of four cultivars in two response groups ['Cheyenne' and 'Rainier White' (group II) and 'Tampico' and 'Potomac' (group III)]. The group II cultivars were the earliest to harvest, but at the expense of quality. Grades of first, extra, and fancy only were harvested. Group III cultivars were harvested with all grades; first, extra, fancy and special. Group II cultivars generally had weaker stems and were of lower dry weight. Night air temperature had the greatest effect on days to harvest. Harvest date was reduced more than 14 days, but at the expense of quality and dry weight. Root-zone heating decreased quality of the group II cultivars at either night air temperature. but reduced quality of the group Ill cultivars only at high night temperatures. Root-zone heat and high night air temperature reduced the number of days to harvest, also at the expense of quality. The majority of high quality stems were from group Ill cultivars harvested from rooms with low night temperatures without root-zone heat. 
EFFECTS OF FERTILIZER TYPE AND RATE AND LIMING ON BANANA SQUASH

Vincent Russo, USDA/ARS, SCARL, Lane, OK 74555

There is a question whether it is best to use synthetic or organic materials to fertilize horticultural crops. Fertilizer rate can effect nutritional value of banana squash (Curcubita maxima Duch.) which is used in processed food. Seed were planted in 1990, 1991 and 1992 into beds treated with recommended (base) and twice the recommended (2X) rates of synthetic or organic fertilizers. Lime was or was not first applied in spring 1991. Synthetic fertilizer produced better yields than organic fertilizer. In 1990, the base fertilizer rate improved yield. In 1992, the 2X fertilizer rate improved yield. Liming did not affect yield. Beginning soil $\mathrm{pH}$ was 5.55. For lime augmented treatments soil $\mathrm{pH}$ was increased to, and maintained at, 5.65 through fall 1992. For no-lime treatments soil $\mathrm{pH}$ was approximately 5.3 through fall 1992. Organic materials, likely bound to soil under acidic conditions, are less available and could explain lower yields. The data suggests that soil $\mathrm{pH}$ will have to be improved before banana squash yields can be increased using organic fertilizers.

\section{EFFECTS OF MODIFIED ATMOSPHERE STORAGE ON THE LONGEVITY OF PHALAENOPSIS}

Peter J. Verpano* and Alton J. Pertuit, Jr.

The packaging of flowering Phalaenopsis sp. plants in sealed plastic film offers advantages in protecting them from the hazards of retail distribution. Following treatments, twoyear old plants, each with three to nine open florets, ware stored at $21^{\circ} \mathrm{C}$ for 76 days under natural light and natural day lengths. Plants were sealed individually in bags of air, bags of $15 \% \mathrm{O}_{2}, 22.5 \% \mathrm{CO}_{2}, 62.5 \% \mathrm{~N}_{2}$, and bags of $20 \% \mathrm{O}_{2}, 30 \% \mathrm{CO}_{2}, 50 \% 2$ $\mathrm{N}_{2}$. Control plants were left in open air and only they were watered twice weekly. Others were not watered. $\mathrm{O}_{2}, \mathrm{CO}_{2}$, and $\mathrm{N}_{2}$ levels in the sealed bags were monitored twice weekly using a syringe and a gas partitioner. Mean inflorescence life values were $40,43,43$, and 38 days, respectively. The various atmospheres had no effect on floret life. Two distinct

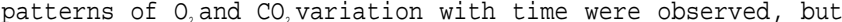
inflorescence half-life values were not related to these patterns. Florets on plants in bags had a greater incidence of discoloration.

MUSCADINE GERMPLASM EVALUATION IN THE GULF SOUTH

Creighton Gupton* and Barbara Smith, USDA-ARS Small Fruit Research Station, Poplarville, MS 39470

Twenty-two muscadine (Vitis rotundifolia) cultivars wars planted in a 4-replication randomized complete block design to 1) accumulate elite germplasm 2) evaluate germplasm and catalog traits that are potentially useful in breeding programs for improving quality and reducing diseases of muscadines consumed as wine, unfermented products, or fresh fruit, and 3) identify cultivars that have acceptable fresh fruit quality. Harvest date ranged from 25 August 92 for 'Southland,' 'Sugargate,' and 'Summit' to 17 September 92 for 'Doreen,' and 'Watergate'. 'Magnolia,' 'Doreen,' 'Janebell,' 'Higgins,' 'Carlos,' and *Welder' produced the highest yields and 'Sugargate,' 'Black Beauty,' 'Fry Seedless,' 'Jumbo,' and 'Sweet Jenny' were the lowest yielding cultivars. The

largest berries were produced by 'Black Beauty,' 'Sweet Jenny,' 'Sugargate,' 'Supreme,' and 'Jumbo'. 'Fry Seedless,' 'Nobel,' 'Welder,' 'Doreen,' 'Hunt,' 'Southland,' and 'Sterling' produced the smallest berries. Virtually no ripe rot was found on any cultivar. 'Doreen,' Fry Seedless, 'Nobel,' 'Supreme,' and 'Welder' were practically free of all disease. The most promising fresh fruit cultivars were

'Supreme,' 'Sweet Jenny,' and 'Black Beauty'.

SUPPLEMENTAL CALCIUM AND UNICONAZOLE INLFUENCE GROWTH OF 'GUTBIER V-14 GLORY' POINSETTIAS.

Steven E. Newman' and Jesse R. Quarrels. Department of Horticulture, Mississippi Agricultural and Forestry Experiment Station, P.O. Drawer T, Mississippi State, MS 39762-5519.

The objective of this study was to determine the influence of uniconazole and calcium applied as a drench or foliar spray to 'Gutbier V-14 Glory' poinsettias'. Uniconazole was drenched into half of the plants at $6 \mathrm{mg} / \mathrm{pot}$. Calcium was applied weekly as either a spray, drench, or a combination of both at $350 \mathrm{ppm} \mathrm{Ca}$. Uniconazole reduced plant height, bract dry weight, and plant dry weight. Bract dry weight from plants not treated with uniconazole and received calcium as a spray was less than from those plants that received either no supplemental calcium or calcium as a drench. Calcium improved the appearance of plants treated with uniconazole.
THE EFFECT OF ULTRAVIOLET LIGHT-C ON STORAGE ROTS AND RIPENING OF TOMATOES J. LIU, C. Stevens*, V.A. Khan, J.Y. Lu, C.L. Wilson, O. Adeyeye, M.K. Kabwe, L. Pusey E. Chalutz, T. Sultana and S. Droby Dept. Plant \& Soil Science Tuskegee Univ. Tuskegee Inst. AL. 36088. USDA/ARS Appalachian Fruit Research Station, Kearneysville, WV. 25430. AL. 36088. USDA/ARS Appalachian Fruit Research Station, Kearneysville, WV. 25430.
USDA/ARS Southeastern Fruits and Tree Nut Research Laboratory, Byron, GA. 31008. ARO USDA/ARS Southeastern Fruits an
Volcani Center, Bet Dagan, Israel

The application of low hormetic low-dose ultraviolet light (WV-C, $254 \mathrm{~nm}$ ) on fruits and vegetables to stimulate beneficial responses is a new method for controlling storage rots and extending the shelf-life of fruits and vegetables. The present study was aimed at rots and extending the shelf-life of fruits and vegetables. The present study was aimed at
treating tomatoes (lycopersicon esculentum) with different UV-C dosages (1.3 to $40 \mathrm{KJ} / \mathrm{m} 2)$ to induce resistance to black mold (Alternaria alternata), gray mold (Boytris cinerea), and Rhizopus soft rot (Rhizopus stolonifer). Thesediseases were effectively reduced when tomatoes were artificially inoculated following UV-C irradiation UV-C treated tomatoes were firmer in texture and less red in color than the control tomatoes, indicating a delay in ripening. Slower ripening and resistsace to storage rots of tomatoes are probably related. The positive effect of UVC on tomatoes decreased as treatments were performed at stages of increased effect of
ripeness.

PRODUCING SWEET CORN TRANSPLANTS IN A FLOAT SYSTEM GREENHOUSE Winston Dunwell*, Dwight Wolfe, William Maksymowicz, and Darrell Slone, University of Kentucky, Research and Education Center, P.0. Box 469, Princeton, KY 42445

Alternative use for float system greenhouse space is being studied in Kentucky. High sugar sweet corn (Zea mays L.) cultivars direct seeded into cool soils germinate poorly. A float transplant production system was used to produce high sugar sweet corn transplants that could be planted into cool soils. 100 seeds of sugar enhanced (se) 'How Sweet It Is' and super sweet (sh2) 'Early Xtra Sweet' sweet corn cultivars wars seeded into trays with a cell size of either 19 or $49 \mathrm{ml} / \mathrm{cell}$. The trays were floated on heated or unheated water in the greenhouse. Percent germination was significantly influencedby cultivar. A greater percent germination was observed for 'How Sweet It Is' compared to 'Early Xtra Sweet' and for seeds sown in the $49 \mathrm{ml} / \mathrm{cell}$ trays compared to the $19 \mathrm{ml} / \mathrm{cell}$ trays. No significant differences resulted from varying the water temperature. Transplants were planted into cool soils with direct seeded sweet corn on April 21, 1992. The use of transplants resulted in a significantly greater plant stand and a two week earlier harvest than the use of the direct seeding.

\section{IMPLEMENTING IPM IN KENTUCKY COMMERCIAL APPLE ORCHARDS}

G.R. Brown. J. Hartman, R. Bessin, T. Jones, and J. Strang. University of Kentucky Research and Education Center, P.O. Box 469, Princeton Ky 42445

Apple growers would like to use pesticides efficiently and diminish concerns about food safety and pesticide usage. The 1992 Apple IPM Program objectives were: 1) to demonstrate the application of Integrated Pest Management practices in commercial orchards and, 2) to provide the training and support needed to help these growers become self sufficient in IPM practices. Grower training meetings and regular scouting of the orchards were the primary educational methods. End-of-the-season evaluations of past and disease incidence were made. Except for Frogeye Leaf Spot, there were no significant differences in insect pest, disease levels or in fruit quality attributes in IPM versus standard blocks. The IPM blocks had significantly more mite incidence. Growers did produce commercially acceptable crops using IPM based decisions while reducing the average past control cost by $\$ 56$ par acre. Educational programs did help growers to be more proficient in making IPM based decisions.

\section{MORPHOLOGY AND YIELD OF PAPRIKA PEPPER IN RESPONSE TO} METHOD OF STAND ESTABLISHMENT

Brian A. Kahn*, James R. Cooksey, and James E. Motes, Department of Horticulture and Landscape Architecture, Oklahoma State University, Stillwater, OK 74078-0511

Raw seed, primed seed, and transplants were compared for effects on stand establishment, plant morphology, and yield of paprika pepper (Capsicum annuum L.) Raw seed seemed satisfactory for stand establishment, although primed seed had the potential to provide better initial stands. When populations were equalized, there were few differences in plant growth, plant morphology, or fruit yield attributed to seed treatment. Morphology of plants established by direct seeding generally was favorable for mechanical harvest. Use of transplants did not result in higher marketable fruit yields than direct seeding in two out of three years. When compared to plants established by direct seeding, three trends were consistent across all three years for plants established by transplanting: a) they were more massive: b) they had larger vertical fruiting planes: and c) they had more branches. These traits would increase the difficulty of mechanical harvest and would create the potential for more trash in the harvested product. Thus, transplanting is not recommended for stand establishment of paprika intended for mechanical harvest. 
ENDOGENOUS HORMONE LEVELS OF PECAN NUTS DURING STRATIFICATION AND STORAGE AT 10C

Frank B. Matta* and Pedro Jover, Department of Horticulture, Mississippi State University, Mississippi State, MS 39762

An experiment was conducted to determine emergence, free abscisic acid (ABA), and total indoleacetic acid (IAA) levels of 'Hughes' and 'Owens' pecan nuts subjected for 45, 90, and 135 days to stratification and storage at 10C; 'Hughes' nut showed a positive relationship between emergence and days in stratification. However, free $A B A$ and total IAA were not related to days in stratification. Emergence percentages of 'Hughes' and 'Owens' were negatively related to days of storage at 10C. Emergence was not related to levels of free $A B A$ or IAA. Free ABA levels and total IAA levels of 'Hughes' were negatively related to days in storage at $10 \mathrm{C}$.

\section{CHANGES IN PECTIN AND HEMICELLULOSE IN 'BELLE OF} GEORGIA' PEACHES DURING SOFTENING.

Supreetha Hegde* and Niels Maness, Department of Horticulture and L.A., Oklahoma State University, Oklahoma State, OK 74075

The mechanism of softening was studied in a rapidly softening peach cultivar 'Belle of Georgia' by assessing changes in pectins and hemicellulose from enzymically inactive cell walls. Cell wall preparations were sequentially extracted with imidazole and sodium carbonate (pectin extracts), and potassium hydroxide (hemicellulose extracts). The pectin extracts were particularly enriched in galacturonic acid, arabiiose and rhamnose, and contained only small amounts of hemicellulose associated sugars. Hemicellulose extracts were enriched in xylose, glucose, mannose, and fucose. More tightly bound hemicellulose fractions contained considerable amounts of pectin associated sugars. The proportion of pectin associated sugars in hemicellulose extracts was greater for cell wall extracts of softened fruit. Some possible relationships between pectin/hemicellulose solubility and fruit softening will be presented. Work was supported by USDA grant 90-34150-5022 and the Oklahoma Agricultural Experiment Station.

EFFECTS OF ROW COVERS ON YIELD OF WHITE POTATOES IN MISSOURI Mack A. Wilson*, Department of Agriculture, Southeast Missouri State University, Cape Girardeau, MO 63701 and Victor A. Khan and Clauzell Stevens, George Washington Carver Agriculture Experiment Station, Tuskegee University, AL 36088

Four types of row covers were evaluated on two cultivars of potatoes ('Atlantic' and Frito-Lay 795') at Charleston, Missouri on sandv loam entisol. Row covers used were spunbonded polyester, clear and white slitted and were spunbonded polyester, clear and white slitted and VisPore. Significant interactions occurred in the sub-plot (row cover $x$ varieties) and sub-subplots (varieties $x$ flower treatments) for numbers of grade A potatoes. The total numbers of potatoes for 'Atlantic' and 'Frito-Lay 795' cultivars as influenced by flower removal and row cover treatments showed significant interactions of row covers $x$ varieties and varieties $x$ flower treatments. Yield of grade A potatoes for both cultivars as influenced by flower removal and row cover treatments showed a significan interaction between row covers $x$ varieties. Genetic differences occurred among potato cultivars in response to flower removal. cultivar response to row covers were also different based on genetic makeup. Clear and spunbonded polyester were superior to other types of row covers for grade A numbers and yield of potatoes.

INTERIORSCAPE PLANTS-THE EFFECT OF FERTILITY SOURCE AND HYDROPHYLIC POLYMER ON EXTENDING WATERING TIME. Melinda S. Conner* and Gerald Klingaman, Department of Horticulture and Forestry, University of Arkansas, Fayetteville, AR 72701 Interiorscape conditions were used to compare plant growth and water use between a commercially produced medium with hydrophilic polymer and a traditional peat-lite medium. $15 \mathrm{~cm}$ pots of parlor palm and pothos were grown in either the medium with polymer or a peat-lite medium. Fertilizer treatments applied to both media included: $1.2 \mathrm{~kg} \mathrm{~N} / \mathrm{m}^{3}$ Osmocote $14 \mathrm{~N}-6.1 \mathrm{P}-11.6 \mathrm{~K}$ and $500 \mathrm{ppm}(\mathrm{mg} / \mathrm{kg}) \mathrm{N}$ of Peter's 20N-8.7P$16.5 \mathrm{~K}$. Plant height, width, top fresh and dry weight, quality and foliage color were determined for parlor palm and top fresh and dry weight and quality were determined for pothos. Plants grown in the peat-lite medium receiving either liquid fertilizer or slow-release fertilizer were significantly greater in all parameters measured than those growing in the medium with polymer that received liquid fertilizer. Plants grown in the medium with polymer had greater growth and quality with the slow-release fertilizer than liquid fertilizer treatments. The number of days until watering was not extended in the medium with hydrophilic polymer.
Tissue Culture of Cowpea and Pigeonpea

Lurline Marsh* and Moshen Dkhill, Department of Agriculture, Lincoln University, Jefferson City, Mo 65102-0029

Tissue culture of four cowpea (Vigna unguiculata) and two pigeonpea (Cajanus cajan) genotypes was tested on Blaydes' medium supplemented with different hormone concentrations. Explants of cotyledonary nodes, cotyledons and leaves of the cowpea genotype IT82E-16, IT64E-124, Pinkeye Purple Hull and MN13 produced callus after 4 weeks in Blaydes' medium. The hormone combinations in the medium were 2-1 dichlorophenoxy acetic acid (2.4-D) (2 mg/liter) and kinetin at $0.05,0.1,0.5 \mathrm{mg} / 1 \mathrm{iter}$, or $2,4-\mathrm{D}$ and thidiazuron (TDZ) at 2.2 , 4.4 and $6.6 \mathrm{mg} / 1$ iter or benzylaminopurine (BA) at $2.25,4.5$ or 6.75 $\mathrm{mg} / \mathrm{liter}$. Shoots occured on cotyledonary nodes of Pinkeye Purple Hull In the TDZ $(6.6 \mathrm{mg} / \mathrm{liter})$. Roots were produced from the leaf and cotyledonary nodes of Pinkeye Purple Hull and on cotyledons of IT64E-124 cultured In media with kinetin $(0.5 \mathrm{mg} / \mathrm{liter})$. Leaf and cotyledon explants of pigeonpea genotype; ICPL 146 1965HK and ICPL 65024 produced callus and some shoots in BA $(2.25 \mathrm{mg} / \mathrm{liter})$ after 4 weeks. The callus when subcultured on BA $(0.5 \mathrm{mg} / \mathrm{liter})$ and NAA $(0.1 \mathrm{mg} /$ liter $)$ produced shoots. Regenerated shoots rooted in the Blaydes' medium with kinetin $(0.01 \mathrm{mg} /$ liter $)$ and NAA 10.6 $\mathrm{mg} / \mathrm{liter})$.

YIELD AND QUALITY EVALUATION OF SEVEN STRAWBERRY CULTIVARS IN EASTERN OKLAHOMA

D.R. Chrz*, N.O. Maness and I. Wahem, Department of Horticulture and Landscape Architecture, Oklahoma State University, Oklahoma State, OK 74075

Seven different quality attributes were assessed during the early, middle and late phases of harvest for years 1990-1992: marketable berry yield, berry weight, berry firmness, berry color (tri stimulus chromameter "a" value), percent soluble solids, percent titratable acidity (percent cinic acid) and the ratio between soluble solids and titratable acidity. Marketable berry yield was influenced by harvest year, harvest season and cultivar. Berry weight varied substantially between cultivars and between seasons. Berry color remained stable through the harvest seasons with slight differences in color between cultivars. Berry firmness differences were generally associated with cultivar and varied little through the harvest seasons. Berry flavor (indicated by the ratio between soluble solids and acidity) tended to remain stable through the harvest seasons with considerable differences between cultivars. Work was supported by USDA grant 90-341505022 and the Oklahoma Agricultural Experiment Station.

\section{Postharvest \& Biotechnology}

POSTHARVEST QUALITY OF WATERMELON CULTIVARS P.M. Perkins-Veazie* ${ }^{1}$, J.K. Collins ${ }^{1}$ N. Maness ${ }^{2}$, and B. Cartwright ${ }^{3},{ }^{1}$ USDA-ARS, South Central Agric. Res. Lab., Lane, OK 74555: '2Dept. Horticulture, Oklahoma State Univ., Stillwater, OK 74078; ${ }^{3}$ Dept. Entomology, WWAREC, Lane, OK 14555.

A study was conducted to characterize the quality of seedless and seeded watermelon. The seeded cultivars 'Jubilee', 'Black Diamond' and 'Allsweet' were compared with seedless 'King of Hearts' for firmness, lycopene content, rind thickness, soluble solids concentration (SSC), ascorbic acid, sugar composition, sweetness index and sensory qualities. 'King of Hearts' melons had higher firmness and lycopene values but a lower sweetness index compared with the other cultivars. 'Black Diamond' and 'Jubilee' cultivars had greater rind thickness compared to the other cultivars. 'Allsweet' and 'Jubilee' fruit had the highest ascorbic acid concentration. 'Black Diamond' had greater fructose and glucose levels than 'Jubilee' or 'King of Hearts' but was lowest in SSC. Untrained taste panelists preferred 'Jubilee' and 'Allsweet' melons. In this study, SSC, sugar composition, sweetness index or firmness were not good indicators of watermelon preference. 
CHANGES IN BLACKBERRY FRUIT QUALITY DURING STORAGE

P. M. Perkins-Veazie*', J. K. Collins' and J. R. Clark

'USDA-ARS, South Central Agricultural Research Center, Lane, OK 74555

'Dept. Horticulture, Univ. Arkansas Fruit Substation, Clarksville, AR 72830

Blackberry fruit are considered highly perishable, having an average shelflife of 2 to 3 days. Fruit of erect blackberry cultivars were stored at $2 \mathrm{C}$ for 7 days to determine shelflife and quality changes. Weight loss was 1.8 and $3.4 \%$ after 3 and 7 days storage, regardless of cultivar or color stage. Soluble solids concentration (SSC), titratable acidity (TA), anthocyanin content, and skin firmness did not change during storage, but differed between ripeness stages and cultivars. Mottled (50\% black) fruit were low in SSC and high in TA compared to shiny or dull black fruit. All dull black fruit were rated softer and lower in overall appearance after storage compared to shiny black fruit. 'Choctaw' fruit were less firm and rated softer and of marginal appearance after 7 days storage while 'Navaho' fruit remained firm and highly acceptable. Ethylene production ranged from 0.4 ('Navaho') to $2.8 \mathrm{nl} / \mathrm{g}$-h ('Choctaw'). Results indicate that erect blackberry fruit harvested at the shiny black stage are of acceptable quality and have excellent shelflife potential.

\section{ETHYLENE EFFECT ON SWEET POTATO SUGAR CONTENT, CHILLING INJURY AND SPROUTING}

B.K. Chegeh and D.H. Picha, Department of Horticulture, Louisiana State University Agricultural Center, Baton Rouge, LA 70803

Cured and non-cured 'Beauregard' and 'Jewel' sweet potato roots were exposed to $0,1,10,100$, and $1000 \mathrm{ppm}$ ethylene for 15 days at room temperature $\left(21^{\circ} \mathrm{C}\right)$. Sucrose and total sugar content increased with increasing ethylene. Fructose, glucose, and maltose content had little or no change, while alcohol insoluble solids decreased with increasing ethylene concentration. Roots exposed to ethylene for 10 days and then chilled at $4.4^{\circ} \mathrm{C}$ for 15 days developed chilling injury symptoms sooner than those free of ethylene. Chilling injury increased with increasing ethylene concentration. Non-cured roots suffered more chilling injury than cured ones. 'Jewel' was more susceptible to chilling injury than 'Beauregard'. Sprout yield was higher in ethylene exposed roots and increased with increase in ethylene concentration. Cured 'Beauregard' roots exposed to ethylene sprouted more than non-cured roots. 'Beauregard' non-cured roots were not stimulated in sprouting by low ethylene concentrations while 'Jewel' (cured and non-cured) roots were stimulated in sprouting by all ethylene concentrations.

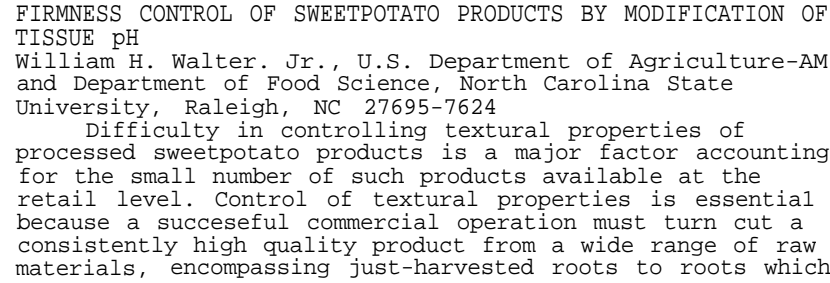

have been stored for up to 10 months. We have developed a process to control the firmess of sweetpotato producta. It involve vacuum infiltration of either acidulants or bases into peeled, sliced sweetpotatoes, followed by heat processing of the infiltrated strips. Using this process, poss from $85-95 \%$ of the initial firmness to $65-75 \%$ of the initial firmn the rate of heat-mediated cleavage of pectic subestances.

EFFECTS OF SHORT TERM CA STORAGE ON PEACH QUALITY Albert C. Purvis, Department of Horticulture, University of Georgia, Coastal Plain Experiment Station, Tifton, GA 31793 Mature, unripe peaches were stored at $1^{\circ} \mathrm{C}$ in air or in $1 \%$ o plus $2.5 \%, 5.01$, or $10.0 \% \mathrm{CO}_{2}$ for 25 days and then ripened in air at $15^{\circ} \mathrm{C}$ for 3 days. Fruit stored in air or $2.5 \% \mathrm{CO}_{2}$ developed browning of the flesh during ripening but fruit stored in 5.0\% or $10.0 \% \mathrm{CO}_{2}$ turned yellow. Only the fruit stored in $10.0 \% \quad \mathrm{CO}_{2}$ softened during ripening, but water soluble pectin content increased and protopectin content decreased in peaches stored in $5.0 \%$ or $10.0 \% \mathrm{CO}_{2}$. Low temperature storage apparently interferes with the levels and/or activities of the pectin degrading enzymes during subsequent ripening of peaches. High levels of $\mathrm{CO}_{2}$ during low temperature storage appears to reduce chilling injury by protecting the capacity of the fruit to produce adequate levels of the pectolytic enzymes at ripening temperatures.

CRITICAL VOLATILES IN THE FIAVOR OF THE SWEETPOTATO Stanley J. Kays ${ }^{1}$, Jyh-Bin Sun Ray F. Severson ${ }^{21}$ Department of Horticulture, The University of Georgia, Athens, GA 30602-7273; 'Phytochemical Research Unit, Russell Research Center, USDA, Athens, GA 30613

Changes in the concentration of individual sugars in sweetpotato storage roots with cooking and their relationship to the formation of volatile compounds were studied. During cooking maltose concentration increased from $0.03 \%$ fwt at 25 .C to a maximum of $4.33 \%$ at WC. Microwave pretreatment (2-4 minutes) resulted in a significant decrease in amounts of maltose and volatiles formed. At $80^{\circ} \mathrm{C}$, approximately $80 \%$ of maltose synthesis was inhibited when pretreated with microwaves. Adding maltose into microwave pretreated samples and then cooking in a convection oven restored most of the volatile profile with the exception of phenylacetaldehyde. Upon heating $\left(200^{\circ} \mathrm{C}\right)$, sweetpotato root material that was insoluble in both methanol and methylene chloride produced similar volatile profiles to those from sweetpotatoes baked conventionally. Volatiles derived via therma degradation of the non-polar methylenc chloride fraction and the polar methano fraction did not display chromatographic profiles similar to those from conventionally baked sweetpotatoes. Initial reactions in the formation of critical volatiles appear to occur in the methanol and methylene chloride insoluble components. Maltol (3hydroxy-2-methyl-4-pyrone) was found to be one of the critical components making up the characteristic aroma of baked sweetpotatoes. It was concluded that maltose represents a primary precursor for many of the volatile compounds emanating from baked 'Jewel' sweetpotatoes and the formation of these volatiles appears to involve both enzymatic and thermal reactions. 